\title{
Measuring Stability and Security in Iraq
}

\author{
October 2005
}

Report to Congress

In accordance with Conference Report 109-72

Emergency Supplemental Appropriations Act, 2005 


\section{Report Documentation Page}

Form Approved

OMB No. 0704-0188

Public reporting burden for the collection of information is estimated to average 1 hour per response, including the time for reviewing instructions, searching existing data sources, gathering and maintaining the data needed, and completing and reviewing the collection of information. Send comments regarding this burden estimate or any other aspect of this collection of information,

including suggestions for reducing this burden, to Washington Headquarters Services, Directorate for Information Operations and Reports, 1215 Jefferson Davis Highway, Suite 1204, Arlington

VA 22202-4302. Respondents should be aware that notwithstanding any other provision of law, no person shall be subject to a penalty for failing to comply with a collection of information if it

does not display a currently valid OMB control number.

\begin{tabular}{|c|c|}
\hline $\begin{array}{l}\text { 1. REPORT DATE } \\
\text { OCT } \mathbf{2 0 0 5}\end{array}$ & $\begin{array}{l}\text { 3. DATES COVERED } \\
\mathbf{0 0 - 0 0 - 2 0 0 5} \text { to 00-00-2005 }\end{array}$ \\
\hline \multirow{3}{*}{$\begin{array}{l}\text { 4. TITLE AND SUBTITLE } \\
\text { Measuring Stability and Security in Iraq }\end{array}$} & 5a. CONTRACT NUMBER \\
\hline & 5b. GRANT NUMBER \\
\hline & 5c. PROGRAM ELEMENT NUMBER \\
\hline \multirow[t]{3}{*}{ 6. AUTHOR(S) } & 5d. PROJECT NUMBER \\
\hline & 5e. TASK NUMBER \\
\hline & 5f. WORK UNIT NUMBER \\
\hline $\begin{array}{l}\text { 7. PERFORMING ORGANIZATION NAME(S) AND ADDRESS(ES) } \\
\text { Department of Defense ,Washington,DC,20301 }\end{array}$ & $\begin{array}{l}\text { 8. PERFORMING ORGANIZATION } \\
\text { REPORT NUMBER }\end{array}$ \\
\hline \multirow[t]{2}{*}{ 9. SPONSORING/MONITORING AGENCY NAME(S) AND ADDRESS(ES) } & 10. SPONSOR/MONITOR'S ACRONYM(S) \\
\hline & $\begin{array}{l}\text { 11. SPONSOR/MONITOR'S REPORT } \\
\text { NUMBER(S) }\end{array}$ \\
\hline
\end{tabular}

12. DISTRIBUTION/AVAILABILITY STATEMENT

Approved for public release; distribution unlimited

13. SUPPLEMENTARY NOTES

The original document contains color images.

14. ABSTRACT

15. SUBJECT TERMS

16. SECURITY CLASSIFICATION OF:

a. REPORT unclassified b. ABSTRACT unclassified c. THIS PAGE unclassified
17. LIMITATION OF ABSTRACT

\begin{tabular}{|c|l|}
$\begin{array}{c}\text { 18. NUMBER } \\
\text { OF PAGES } \\
\mathbf{4 4}\end{array}$ & 19a. NAME OF \\
& \\
&
\end{tabular}




\section{Report to Congress Measuring Stability and Security in Iraq}

This report to Congress is submitted pursuant to the section entitled "Measuring Stability and Security in Iraq” of House Conference Report 109-72 accompanying H.R. 1268, Emergency Supplemental Appropriations Act for Defense, the Global War on Terror, and Tsunami Relief, 2005, Public Law 109-13. This is the second report in the series; the previous report was issued on July 22, 2005.

The report addresses the issues specified in the Conference Report and is divided into two sections corresponding to those identified in the Conference Report. The initial section of the report, "Stability and Security in Iraq," describes trends and progress towards meeting goals for political stability, economic progress, and achieving a stable security environment in Iraq.

The second section of the report, "Security Force Training and Performance," provides indicators of the training and development of the Iraqi Security Forces, including the forces of the Ministry of Defense and the police and other paramilitary forces of the Ministry of Interior.

As with the previous report, this is not the single source of all information about the combined effort of the United States, its Coalition partners, and Iraq. The report complements other reports and information about Iraq provided to Congress. The purpose of the report is to address specific concerns and questions raised by Congress in the course of legislation passed earlier this year. The information in this report is made available with the assistance of many departments and agencies of the U.S. Government, the U.S. Embassy in Iraq, and the Government of Iraq.

A classified annex to this report provides classified data concerning security force training and performance and addresses U.S. military requirements and various possible force rotations.

\section{Overview}

The U.S. Government continues to place emphasis on developing and using metrics that assist the U.S. Government, its Coalition partners, and the Government of Iraq in assessing progress toward achieving objectives in Iraq. The report reflects measures and indicators currently in use for this purpose.

Building from the previous report, this report provides measurable trends indicating progress toward meeting the objectives of the strategy for Iraq. The broad purpose of the strategy is to assist in creating an Iraq that is at peace with its neighbors, is an ally in the war on terror, has a representative government that respects the human rights of all Iraqis, and has security forces that can maintain domestic order and deny a safe haven for terrorists in Iraq. To achieve this end, strategic objectives include: defeating the terrorists and neutralizing the insurgency; transitioning Iraq to security self-reliance; helping Iraq to forge a national compact for 
democratic government; helping Iraq to build government capacity, provide essential services, strengthen its economy, and strengthen the rule of law; increasing international support for Iraq; and increasing public understanding of Coalition efforts and public isolation of the insurgents.

Trends since the last report include the following:

- Political Stability. A key indicator of the development of constitutional and democratic government in Iraq is the continued progress of the political process despite numerous challenges. On August 22, a draft constitution was delivered to the Transitional National Assembly (TNA) by the constitutional drafting committee, meeting the deadline as extended by the TNA; on September 18, the draft constitution was read to the TNA; and the constitutional referendum remains on schedule for October 15. By numerous measures, Iraqi participation in the political process continues to grow. With reports of nearly a million new voters registered since the January election, the greatest growth in new registrants is among the Sunni Arab population. Recent polls indicate that the overwhelming majority of the Iraqis - including Sunnis - intend to vote in the constitutional referendum.

- Economic Activity. Economic indicators provide cause for both optimism and concern. Iraq continued its reintegration into the world economy, holding its first "Article IV" consultations on economic development and reform with the International Monetary Fund (IMF) in 25 years. The IMF commended the Government of Iraq for maintaining a degree of macroeconomic stability under difficult circumstances and initiating structural reforms. It noted grounds for optimism, but stressed that much work remains to fully transform Iraq into a market economy. Iraq's economy continues to grow. The World Bank projects a real growth rate in the Iraqi Gross Domestic Product of 3.7\% for 2005. The growth of the private sector continues. Nonetheless, challenges remain in delivering essential services. During this reporting period, Iraqi production of oil and essential electricity remained stable, although below goals. Electricity briefly exceeded summertime goals, but several targeted infrastructure attacks adversely affected overall electrical and oil production.

- The Security Environment. One noteworthy strategic indicator of progress in the security environment is the continued inability of insurgents to derail the political process and timelines. This is a key objective they are failing to achieve. As expected, there has been an increase in the average number of insurgent attacks during the period leading to the constitutional referendum. Insurgent attacks remain concentrated in four of Iraq's eighteen provinces; half of the Iraqi population lives in areas that experience only six percent of all attacks. Six provinces reported a statistically insignificant number of attacks based on population size. Although about $80 \%$ of all attacks are directed against Coalition Forces, about $80 \%$ of all casualties are suffered by the Iraqi population.

- Iraqi Security Forces. Ministry of Defense and Ministry of Interior forces continue to progress in their ability to take ownership of Iraqi security. This progress has come in a 
relatively short period of time, in the face of a brutal insurgency. Key measures of progress include:

o A continued increase in the number of Iraqi units able to take the lead in combat operations against the insurgency. There are now 88 Iraqi Army and special operations battalions conducting combat operations against the enemy an increase of nine since the July report. Of the 88 operational units, 36 are assessed as being "in the lead" or fully independent - a $50 \%$ increase over units at these levels of readiness in the July report. There are 28 Special Police Force battalions capable of combat operations - an increase of 13 since the last report.

o Progress of Iraqi units in assuming responsibility for the battle space. Since the last report, Iraqi forces have taken responsibility for security in several areas of Iraq and now have the lead in one Iraqi province, roughly 87 square miles of Baghdad and over 450 square miles in other provinces.

o A continued increase in the number of units and individuals trained, equipped, and formed into operational status. More than 87,000 soldiers, sailors, and airmen have now been trained and equipped - an increase of 10,000 since the last report. A total of 68,800 police have been trained and equipped - an increase of 5,500 since the last reporting period. These work alongside 35,500 other Ministry of Interior forces. Overall, this represents a $12 \%$ increase in Ministry of Defense and Ministry of Interior forces trained and equipped for counterinsurgency operations since July 2005. 


\section{Stability and Security in Iraq}

\section{$\underline{\text { Political Stability }}$}

The ultimate goal of the transitional political process is for Iraq to be governed by an effective and representative democratic system that is: supported by the Iraqi people; capable of exercising responsibility for managing Iraq's affairs, including security; accepted as legitimate by the international community; and committed to promoting civil society, the rule of law, and respect for human rights.

To achieve this goal, the United States is supporting Iraqi efforts to forge a national compact for a democratic government, including:

- supporting the on-schedule Iraqi constitutional referendum and national elections;

- supporting Iraqi efforts to ensure that all communities see the political process as the preferred way of protecting their interests; and

- promoting the international community's rhetorical and tangible support of the political process.

\section{Progress towards Constitutional Government}

One key measure of progress towards the establishment of a constitutional and democratic government in Iraq is the timeline and political process set forth in the Transitional Administrative Law (TAL) of March 2004 and United Nations Security Council Resolution (UNSCR) 1546 (June 8, 2004).

The most recent milestone in this process was the successful completion of a draft constitution. Pursuant to the TAL, the Transitional National Assembly (TNA) extended the deadline for submission of the draft constitution from August 15 until August 22, and that deadline was met. The draft constitution was formally read to the TNA on September 18. The draft constitution contains protections for fundamental human freedoms, including religion, assembly, conscience, and expression. It vests sovereignty in the Iraqi people to be expressed by secret ballot and regular elections. It declares that all Iraqis are equal before the law without regard to gender, ethnicity, or religion.

Upcoming markers of democratic progress include a nationwide referendum on the draft constitution in October. If the constitution is approved by a majority of Iraqi voters and not rejected by two-thirds of voters in three or more of Iraq's 18 governorates, elections for a government under the permanent constitution are to be held in December 2005, and the permanent Iraqi government is to take power shortly thereafter. This new Iraqi government would then be responsible for passing enabling legislation to clarify and codify general 
provisions of the new constitution. The new government's progress on enabling legislation would be an important measure of progress in the continuing political process.

If the draft constitution is not approved during the October referendum, pursuant to the TAL the Transitional National Assembly would be dissolved, new elections would be held, and another draft constitution would be written and submitted to a national referendum.

The following graph illustrates the timeline for such process in Iraq, as set forth in the Transitional Administrative Law and UNSCR 1546.

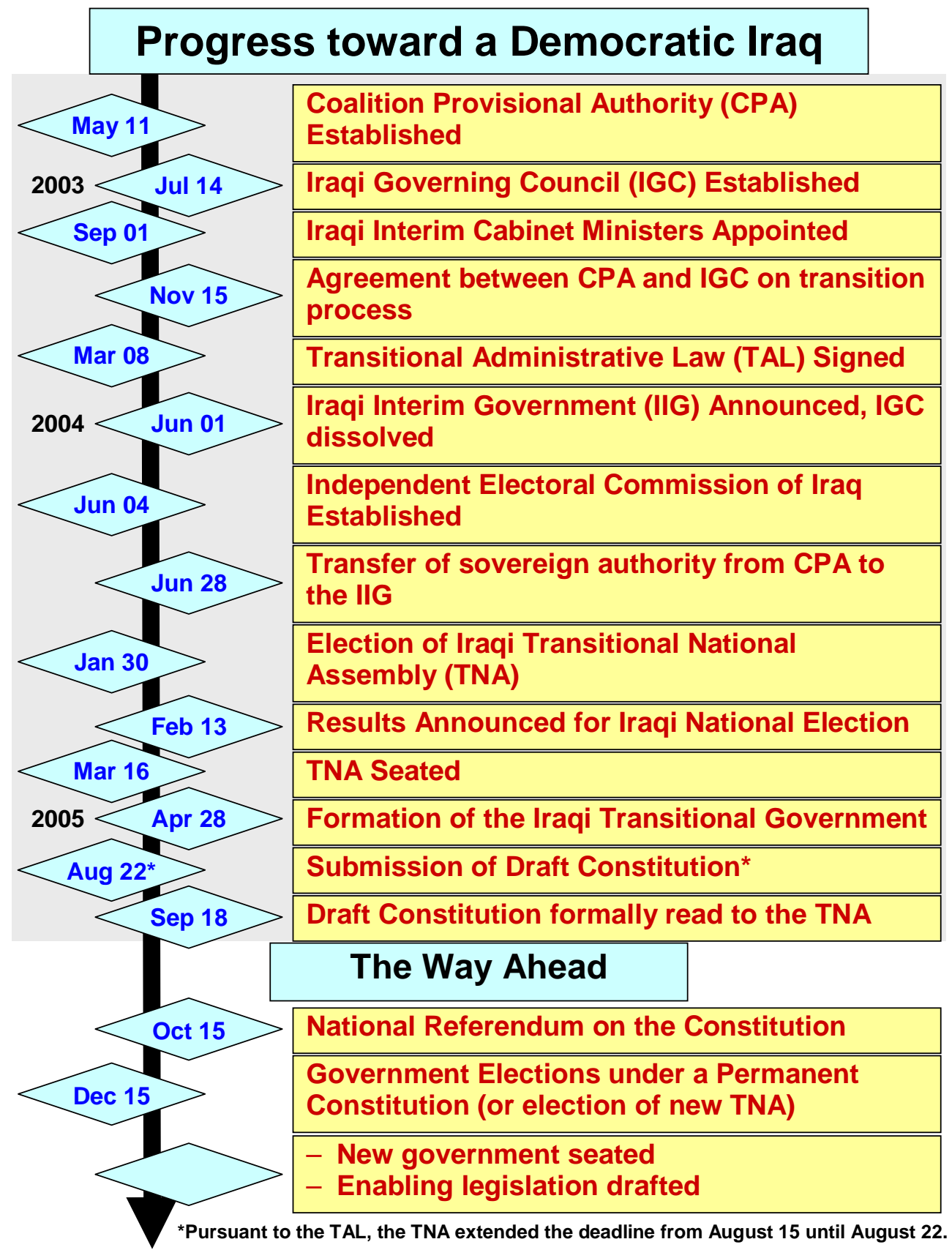




\section{Participation in the Political Process}

Iraqi participation in the political process continues to grow among all communities. More than 8.5 million Iraqis of an estimated 14 million registered voters voted in the January 30 elections. President Talibani has indicated that there are now more than 15 million Iraqis registered to vote in the October referendum. The greatest growth in new registrants is among the Sunni Arab population.

Inclusion of the mainstream Sunni Arab community within the political process is part of the strategy to isolate the violent extremists politically, even as the Iraqi Security Forces and MultiNational Forces-Iraq hunt them down militarily. In retrospect, a majority of Sunni Arabs in predominantly Sunni Arab cities think that the decision to boycott the January 30 elections was a bad idea.

\section{Percentage of Arab Sunnis Who Think the Decision to Boycott the January Election Was Good or Bad}

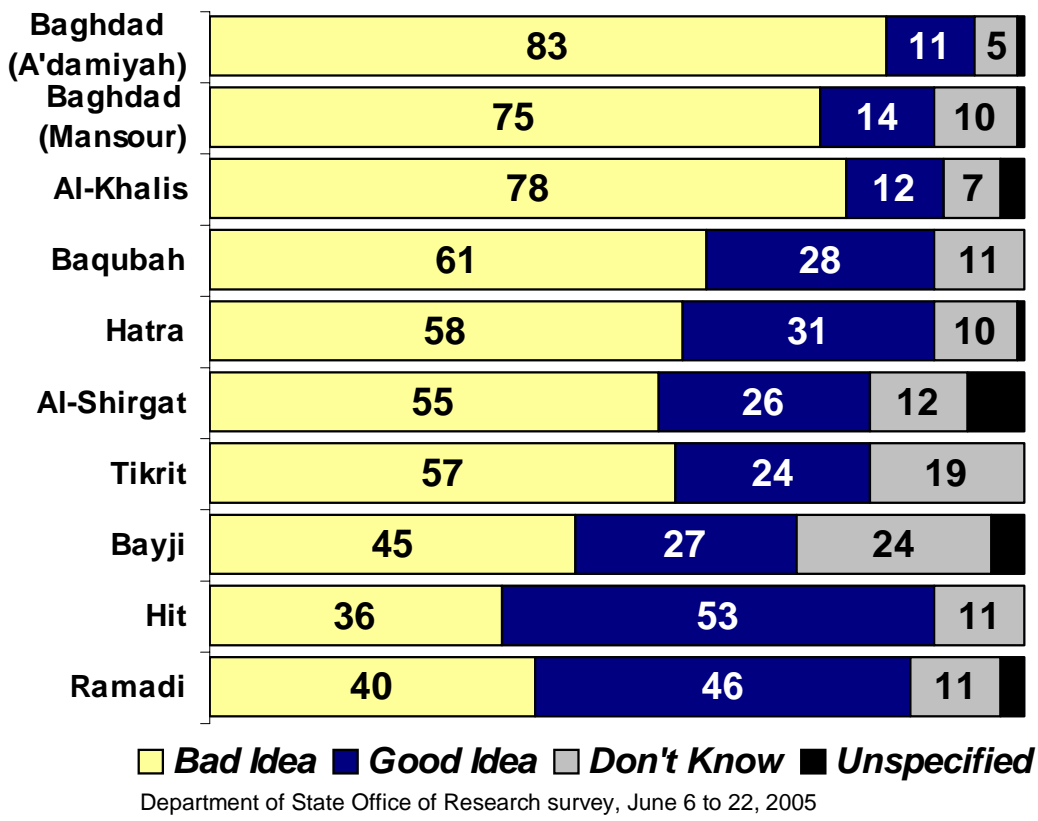

Additionally, Sunni Arabs who say they boycotted the January 30 elections overwhelmingly supported the participation of Sunni leaders in the drafting of the constitution.

The October 15 referendum represents another milestone for the democratic process, regardless of its outcome. Recent State Department polls indicate high voter turnout across all communities, including among Sunni Arabs, thus strengthening the political process and further isolating the violent extremists. Most Iraqis also believe voting is a better strategy than boycotting the referendum. 
Which view is closer to your own?

(regarding the upcoming referendum)

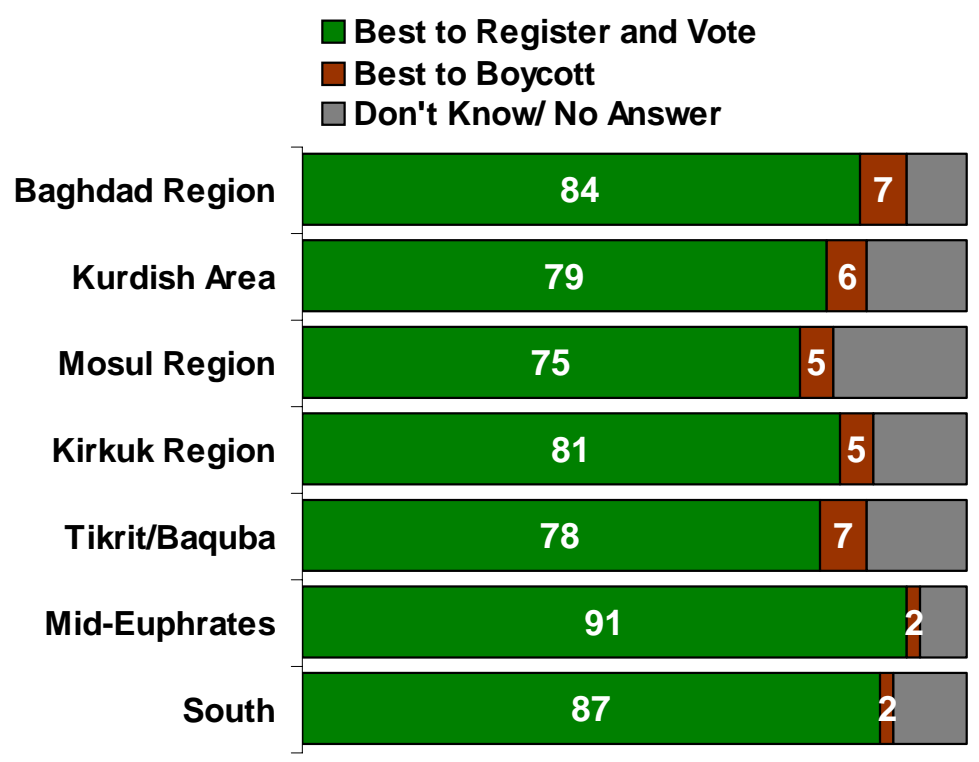

Department of State Office of Research nationwide survey, September 8-15, 2005

A striking indicator of the broader political process is the growth of commercial and independent media in Iraq since liberation. From no independent media under Saddam, there are now 44 commercial television stations, 72 commercial radio stations, and more than 100 independent newspapers and magazines that represent all points of Iraq's political spectrum.

\section{Mass Media Outlet Increase}

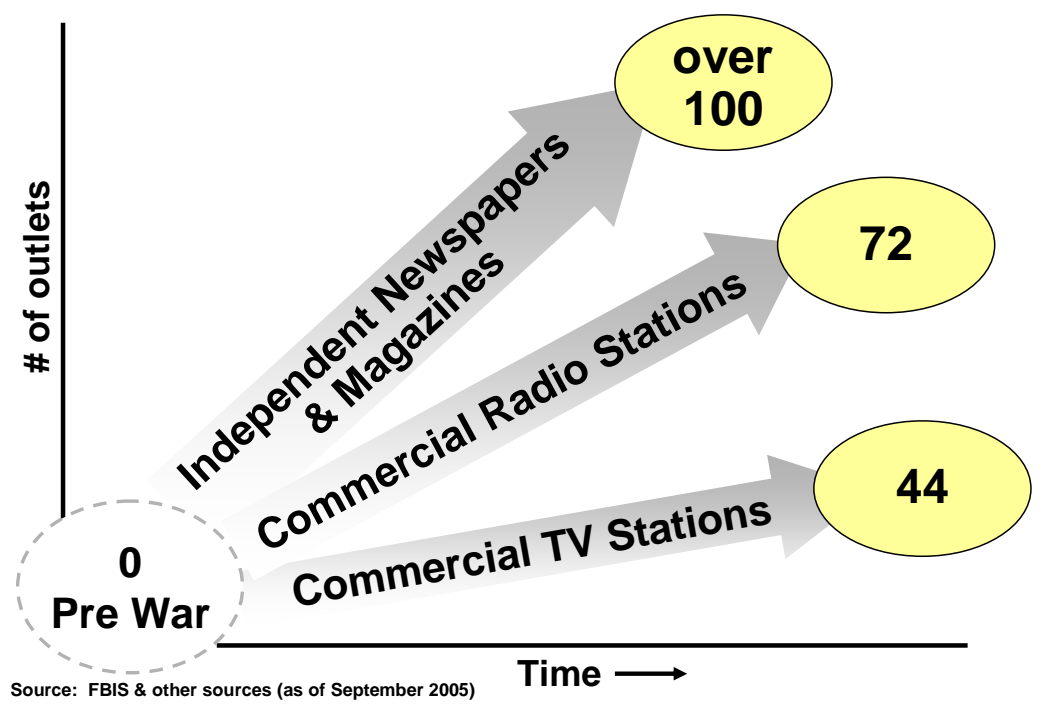




\section{International Support}

The international community and organizations continue to support Iraq's transition to democracy. The United Nations (UN) has actively supported the constitutional development process, with a team of experts resident in Baghdad to provide technical assistance as requested by the Iraqi government. With the aid of the UN, the Transitional National Assembly drafted and passed a new election law on September 12, 2005. The UN also continues to provide assistance to the Independent Electoral Commission of Iraq, which is preparing for the nationwide referendum and the elections later this year.

The international community also continues to affirm its support for Iraqi reconstruction and economic development. A meeting of international donors was held in Jordan on July 18-19, 2005, which resulted in \$235 million in new pledges for the International Reconstruction Fund Facility for Iraq. At this meeting, the Iraqi government operationalized its central leadership role in soliciting and coordinating international support for Iraqi reconstruction. It presented an updated National Development Strategy (NDS), which was well received by donors. Donors, for their part, reaffirmed their support for Iraqi reconstruction. The Iraqi government also presented new donor coordination mechanisms on the ground in Iraq, chaired by Iraq and supported by the United Nations and the World Bank. These mechanisms are intended to facilitate donors' ability to deliver on their pledges, as well as to ensure that donors' resources are used for Iraq's highest priorities as enunciated in the NDS.

Additional international assistance is provided by NATO nations through the NATO Training Mission in Iraq (NTM-I). As noted in the July report, NTM-I provides training and technical assistance to the Iraqi Security Forces. NATO member states have contributed trainers and financial resources, as well as coordination assistance for the transfer of the significant quantities of equipment donated by NATO members and partners to the Iraqi Security Forces. An integral role of NTM-I is to assist in the development of a new Iraqi Staff College. To that end, on July 25, 2005, twenty-four Iraqi instructors completed a 15-week "Train the Trainer" course organized by NTM-I. These new instructors will help mold the next generation of Iraqi officers.

\section{$\underline{\text { Economic Activity }}$}

The goal remains to assist the Government of Iraq to establish the foundation for a strong economy and the capacity to effectively deliver essential services. Assisting the Iraqis to achieve their economic objectives is central to attaining the ultimate goal of a stable, unified, and prosperous Iraq. Those objectives include:

- helping Iraq develop a sustainable national budget and integrate Iraq into the world economic community;

- supporting development of a strong and viable private sector;

- helping Iraq develop the capacity to deliver sufficient essential services; and

- revitalizing and rehabilitating the Iraqi economy through promotion of economic and market-based reforms. 
Iraq continues to make progress on reintegration into the world economy. In addition to U.S. Government and donor assistance, the Government of Iraq is receiving important technical and financial assistance from the World Bank and International Monetary Fund (IMF). Iraq resumed normal relations with the IMF last year and received a \$436 million emergency loan to help rebuild the economy. In August of this year, Iraq concluded "Article IV" consultations on general economic health, economic developments and reform policies with the IMF for the first time in 25 years. The IMF commended the Iraqi government for maintaining a degree of macroeconomic stability under difficult circumstances and initiating structural reforms, and it expressed cautious optimism about the future of Iraq's economy. The IMF stressed, however, that the economy remains fragile and much work needs to be done to transform Iraq into a market economy firmly based on a path of sustained growth. The World Bank plans to provide \$500 million in loans through the International Development Association, with an additional $\$ 500$ million in loans through the International Bank for Reconstruction and Development, if Iraq improves its creditworthiness.

In cooperation with the International Monetary Fund (IMF), Iraq is laying the foundation for strong, stable growth by implementing an economic reform program that includes fiscal and monetary policy reforms, as well as structural reforms. As part of this effort, the Iraqi government is taking significant steps to ensure transparency and credibility in the 2006 budget. Addressing economic reform and developing a stable budget are key steps toward achieving a stand-by arrangement with the IMF and maintaining the generous Paris Club debt reduction agreement with official creditors. The Government of Iraq has also improved its budget outlook by implementing the first phase of its plan to settle all outstanding claims of commercial creditors against the previous Iraq regime. The Government of Iraq has also signed bilateral agreements with two non-Paris Club members (Romania and Malta) forgiving debt at terms comparable to the Paris Club deal.

\section{Macroeconomic Indicators}

Macroeconomic indicators are collected and published on a yearly basis through the Iraq Ministry of Planning and Development Coordination and international organizations such as the World Bank, United Nations Development Program, and the International Monetary Fund. Nonetheless, Iraq's ability to generate regular and comprehensive macroeconomic data is still limited due to the legacy of the previous regime and post-war difficulties. The U.S. Government is providing assistance to improve the capacity of the Ministry of Planning and Development Cooperation, the Central Office of Statistics and Information Technology, the Ministry of Finance, and the Central Bank of Iraq to improve collection and production of reliable data. The State Department's Iraq Reconstruction Management Office is able to track performance metrics on a few indicators on a weekly basis.

Available data reveal that the economy is showing signs of continued recovery. Economic growth continues to be substantially dependent on the performance of the oil sector, as it accounts for over two-thirds of Gross Domestic Product (GDP). Recovery of the sector in 2004 
from its nadir in 2003 led to an increase of almost 50 percent in GDP and an increase in per capita GDP from \$518 to \$942, according to World Bank and International Monetary Fund estimates. However, GDP growth is projected to slow to 3.7 percent in 2005 because problems in the oil sector have led to flat oil production and exports.

\begin{tabular}{|l|l|l|l|l|}
\hline \multicolumn{5}{|l|}{ GDP Estimates and Projections, 2002-2005 } \\
\hline & $\mathbf{2 0 0 2}$ & $\mathbf{2 0 0 3}$ & $\mathbf{2 0 0 4}$ & $\mathbf{2 0 0 5 p}$ \\
\hline Population & 25.5 & 26.3 & 27.1 & 27.9 \\
\hline Nominal GDP (in USD billion) & 20.5 & 13.6 & 25.5 & 29.3 \\
\hline$\quad$ Of which non-oil GDP (\%) & 32 & 32 & 33 & 37 \\
\hline Real GDP Growth Rate (\%) & -7.8 & -41.4 & 46.5 & 3.7 \\
\hline Per Capita GDP (USD) & 802 & 518 & 942 & 1,051 \\
\hline Consumer Price Inflation (annual average) & 19 & 34 & 32 & 20 \\
\hline \multicolumn{5}{|l|}{} \\
\hline
\end{tabular}

Source: World Bank and IMF estimates and projections (p).

Inflation has been relatively moderate for most of 2005, but may remain in double digits for the year due to recent price increases in fuel, electricity and food. Consumer prices were stable after the introduction of the New Iraqi Dinar in early 2004, but accelerated in mid-2004 driven by increased demand, commodity shortages, and increasing security costs.

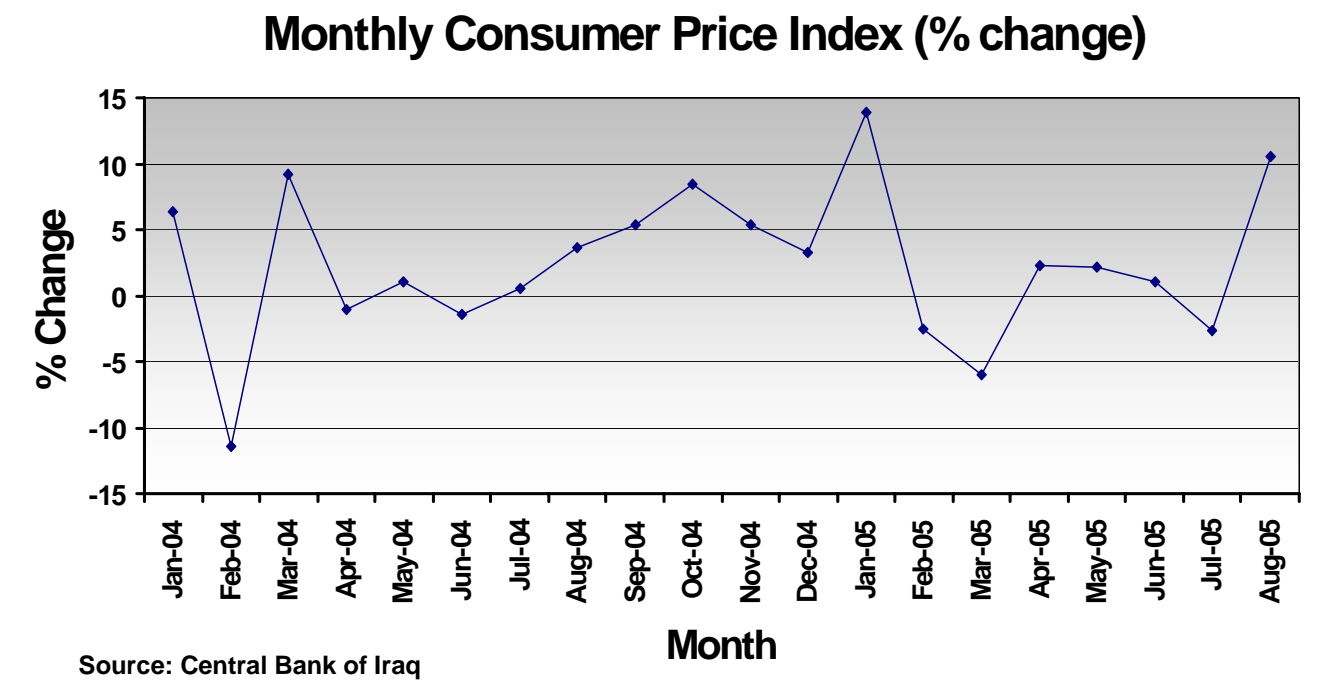

Unemployment remains a concern, although there are substantial difficulties in measuring it accurately. The most recent Government of Iraq report on unemployment released in July of 2004 estimated nationwide unemployment to be 28\%. Current Multi-National Forces-Iraq polling in the Baghdad governorate estimates unemployment to be $21 \%$.

The exchange rate for the Iraqi dinar has been stable since its introduction. A stable currency has enabled the Central Bank of Iraq to manage inflationary pressures more effectively and is one of Iraq’s macroeconomic success stories. 


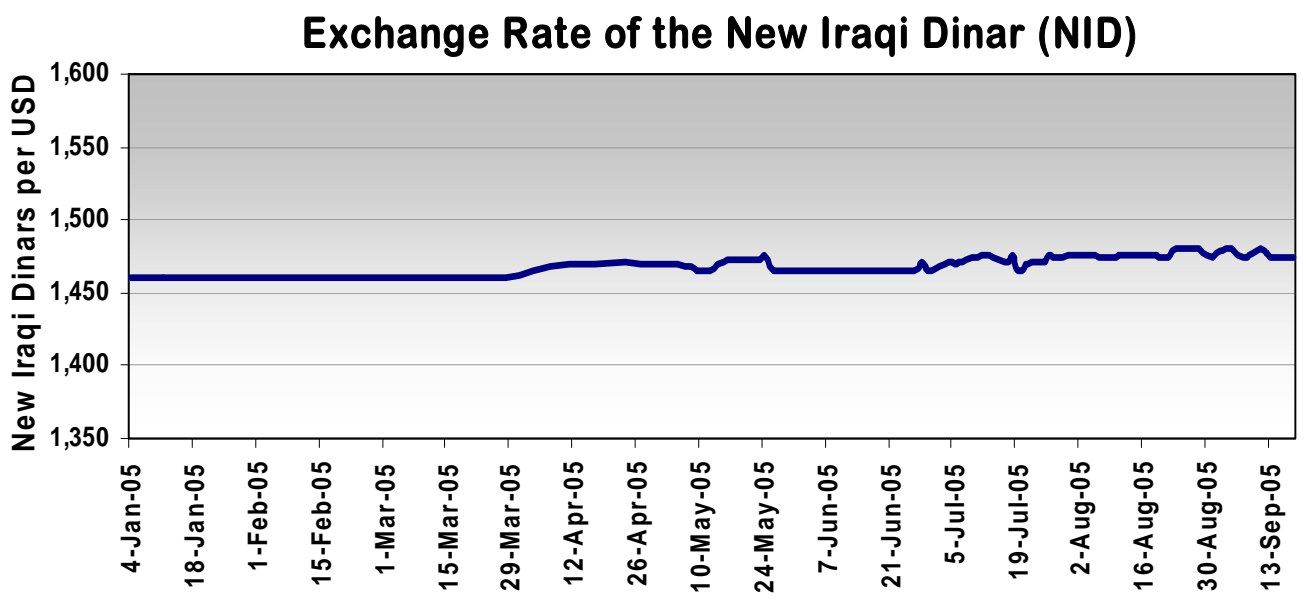

Variation in prices represents less than $2 \%$ of total value of the dinar.

Source: Central Bank of Iraq

There is evidence of continued expansion of Iraqi private sector activity. U.S. Government agencies are attempting to spur private sector activity by providing microfinance loans, bank lending to small and medium sized enterprises, capital market development, business skills development, vocational training, investment promotion, business center support, and establishment of economic zones. More than 30,000 new businesses have registered with the Ministry of Trade - 12,000 since December of 2004, a growth of $67 \%$ in a period of nine months. More than 17,000 micro-loans have been disbursed to new businesses in the past two years.

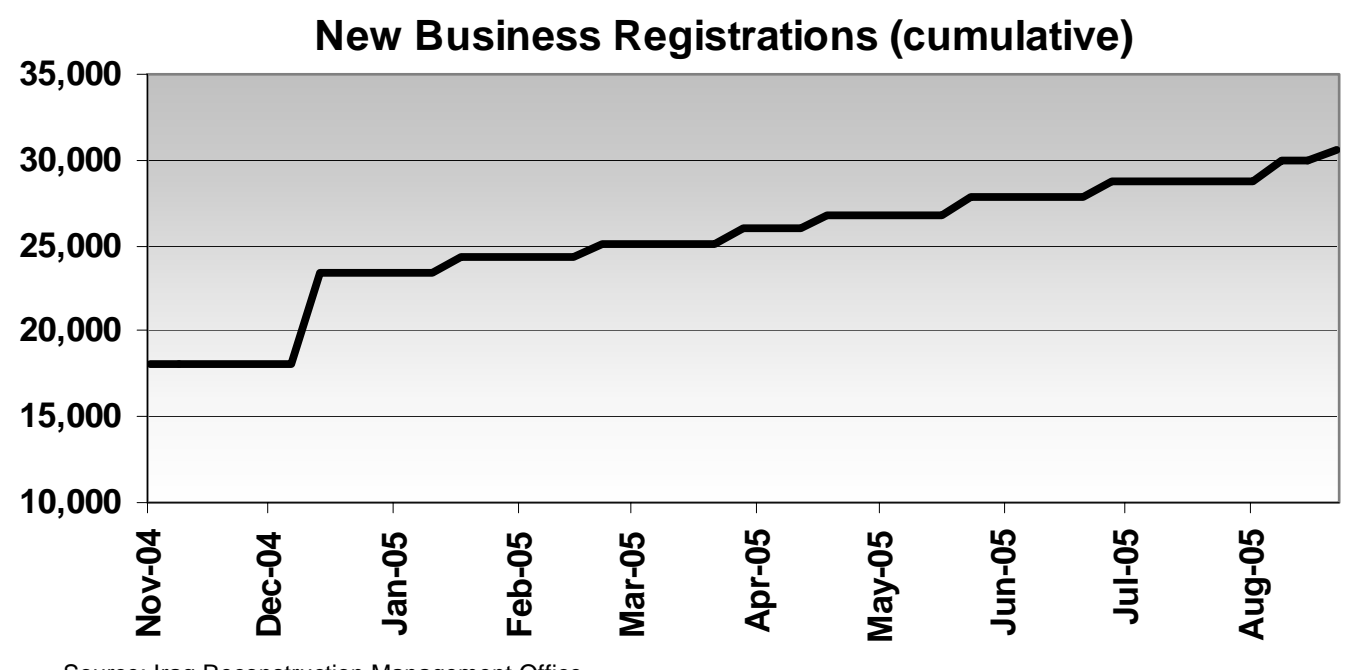

Source: Iraq Reconstruction Management Office

In spite of the significant challenges they continue to face, Iraqi business owners remain optimistic about the growth of the economy and their businesses. According to a recent survey of Iraqi business owners and managers by Zogby International for the Center for International Private Enterprise, 76 percent of the respondents anticipate economic growth over the next two 
years and 69 percent describe themselves as being optimistic about Iraqi's general economic future. Over the next six months, 54 percent of businesses expect increased sales. Businesses plan to hire more employees overall, and 63 percent of Iraqi businesses surveyed now employ women - an almost 50 percent increase over the previous poll in 2004 . Security continues to be the primary concern followed by effective enforcement of laws and regulations, corruption, and better education and training.

Since 2003, liberalized trade and investment regulations have removed many longstanding impediments to conducting business activities, though much remains to be done. These reforms have created a more conducive business environment in Iraq. A recently released World Bank study of indicators of the "Ease of Doing Business" ranked Iraq 114 out of 155 countries surveyed, indicating substantial room for progress, but a respectable showing for a country emerging from 30 years of statism, war and sanctions. This study provides a snapshot of the ease of doing business based on ten topics such as ease of registration of a business, property, trade, and enforcing contracts.

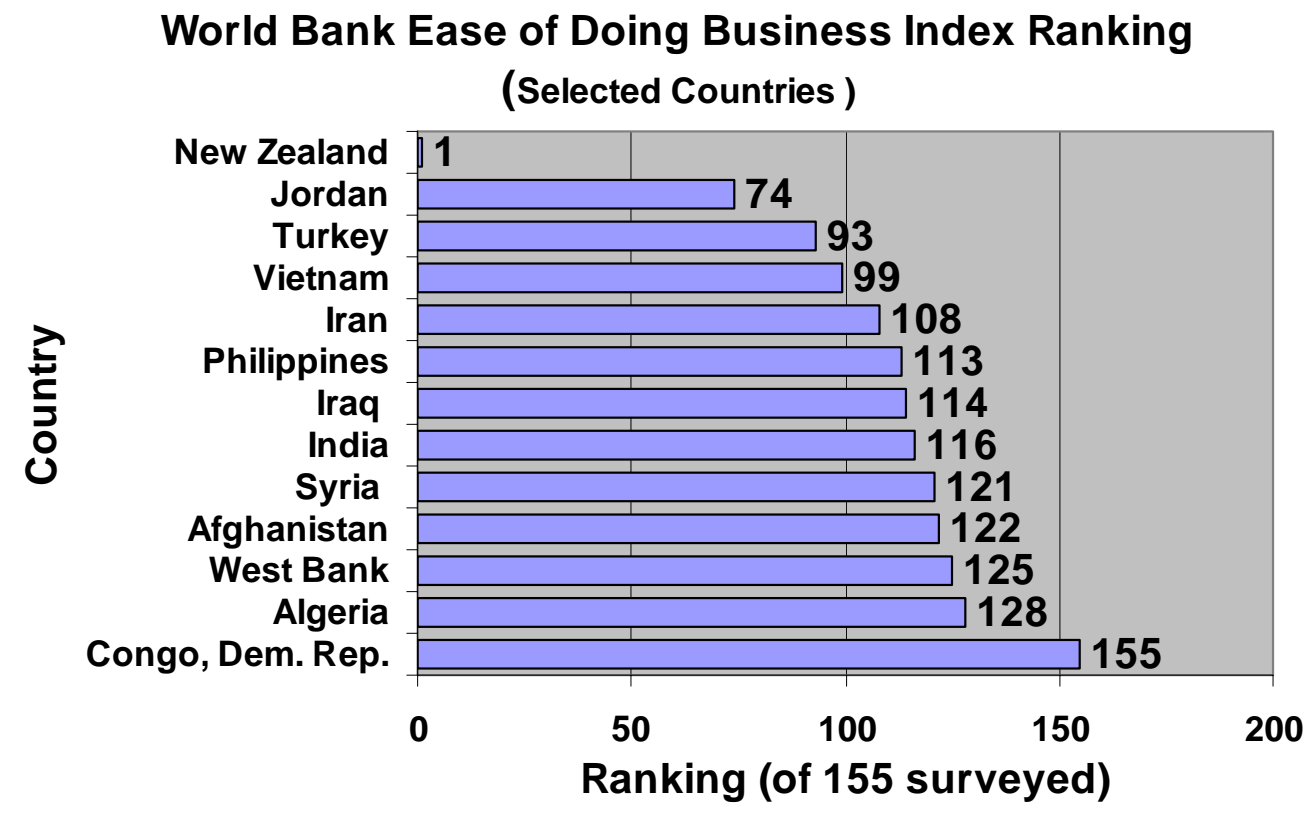

\section{$\underline{\text { Sector Indicators }}$}

\section{Oil Infrastructure}

When Coalition Forces began Operation Iraqi Freedom, they entered a country whose energy infrastructure had deteriorated over many years. The Coalition set out to restore Iraqi oil facilities and restore production to the prewar level of 2.5 million barrels per day while also improving the refining, natural gas, and pipeline facilities. Reconstruction challenges, terrorist attacks, complicated by dilapidated infrastructure and poor maintenance, have slowed progress. 
Beyond attacks on various worksites, terrorists have attacked crude export and petroleum product pipelines, impeding exports and the refining and distribution of petroleum products, such as gasoline and diesel.

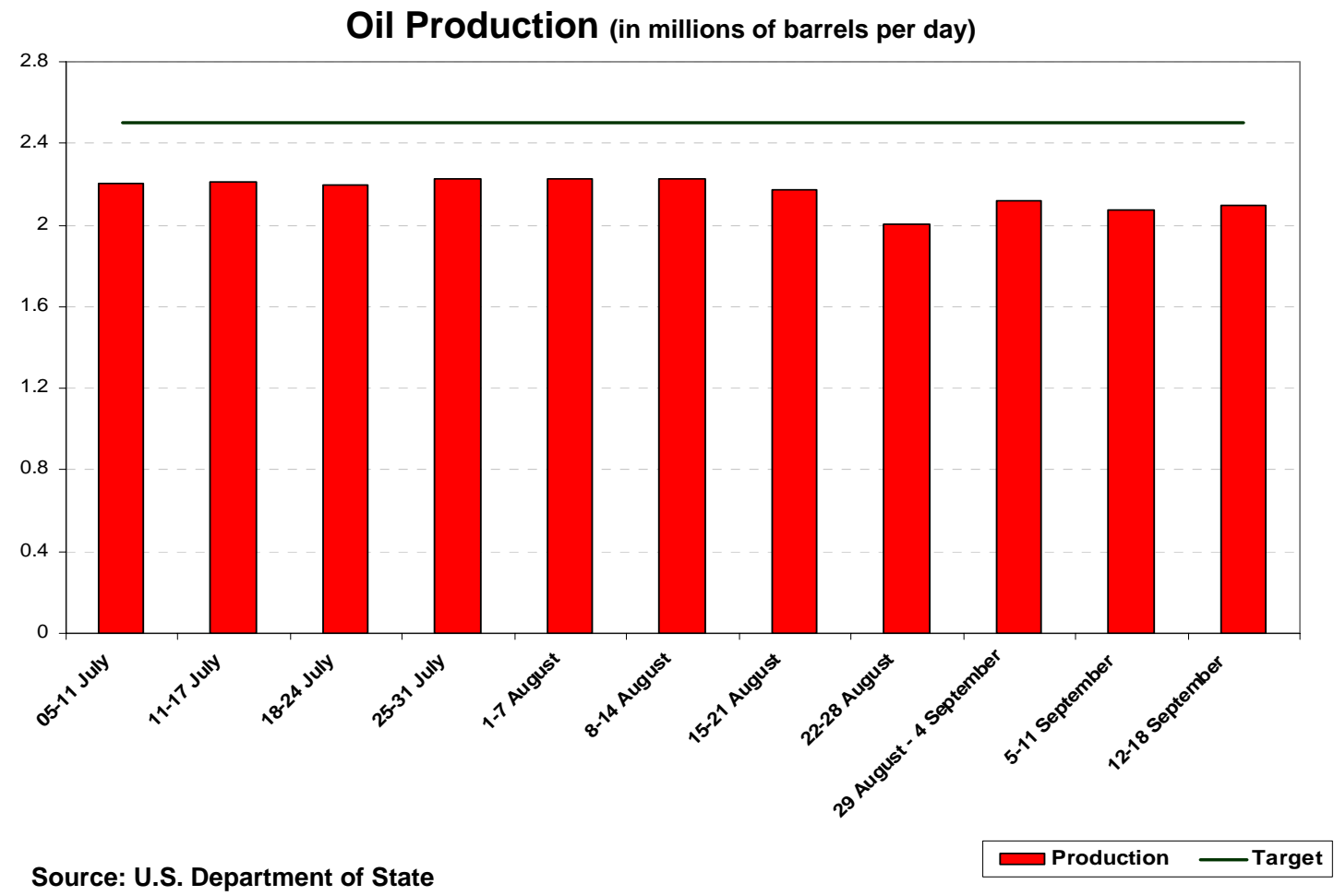

Crude oil production and exports remain flat since the last report, at about 2.16 and 1.42 million barrels per day, respectively. High world oil prices have, however, kept revenues above projections made at the beginning of the year. Progress is being made on some key projects, such as the al-Fatah pipeline crossing in the north, which is vital for increased petroleum product supply and northern crude exports, rehabilitation of gas-oil separation plants, and rehabilitation of the al-Basra Offshore Terminal to increase its export capacity.

The U.S. Government is working with the Government of Iraq to improve infrastructure security (including the formation and deployment of special Iraqi battalions along key supply and pipeline corridors); to institute price reforms for petroleum prices to reduce both demand and smuggling; and to increase capital spending.

\section{Electricity}

Delivering adequate electric power throughout Iraq continues to be difficult due to reconstruction challenges, terrorist attacks, shortages of refined fuel, substandard operations and maintenance practices, increased and unchecked consumer demand, and an infrastructure that has been deteriorating for years. These challenges have partially offset many of the advances that the 
Iraqis and Coalition partners have made in this sector, including the rehabilitation of various units at power plants and training of Iraqis to operate them.

On July 14, 2005, Iraq reached a summer capacity peak of 5,126 megawatts (MW), roughly 25\% above pre-war levels; however, this level has been difficult to maintain given attacks on infrastructure. Additionally, demand for electricity has far outstripped production, as Iraqi consumers acquired air conditioners, refrigerators, televisions, and other electric appliances. In July, this demand reached almost 9,000 MW, approximately 200\% of pre-war demand. The U.S. Government is working with the Iraqis to reduce demand by reducing subsidies of price and improving their collection of fees, to improve their operations and maintenance practices, and by increasing training, while continuing electrical generation and distribution construction projects.

\section{Iraq Electricity Generation (Peak Capacity) and Estimated Demand September 2003 - September 2005}

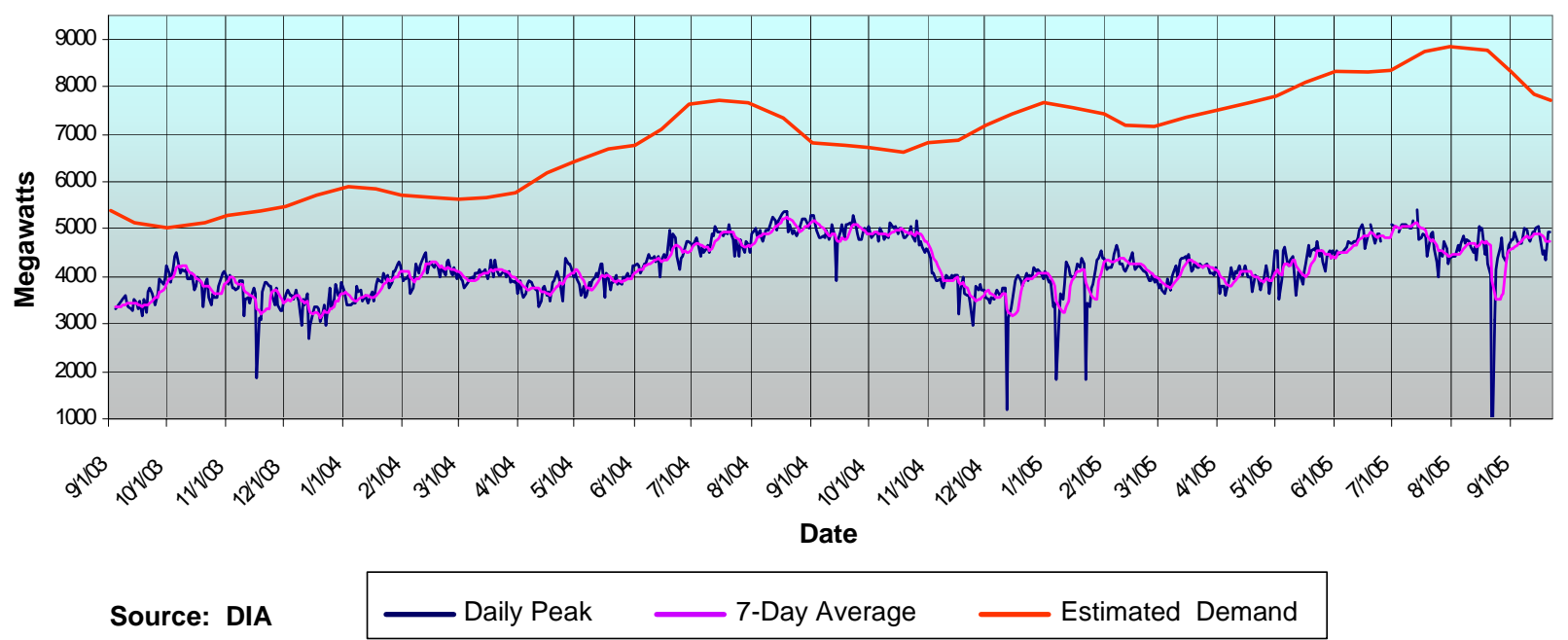

During the reporting period, several large-scale attacks on infrastructure significantly damaged transmission lines, resulting in declining hours of available power and a blackout on August 23, 2005. Peak capacity for the three-month reporting period averaged 4,645 megawatts, and daily load served averaged 101,105 megawatt hours (MWh), although the summer 2005 goal of 110,000 MWh was reached several times. 
Electricity Load Served and Estimated Demand in Iraq Since January 2004

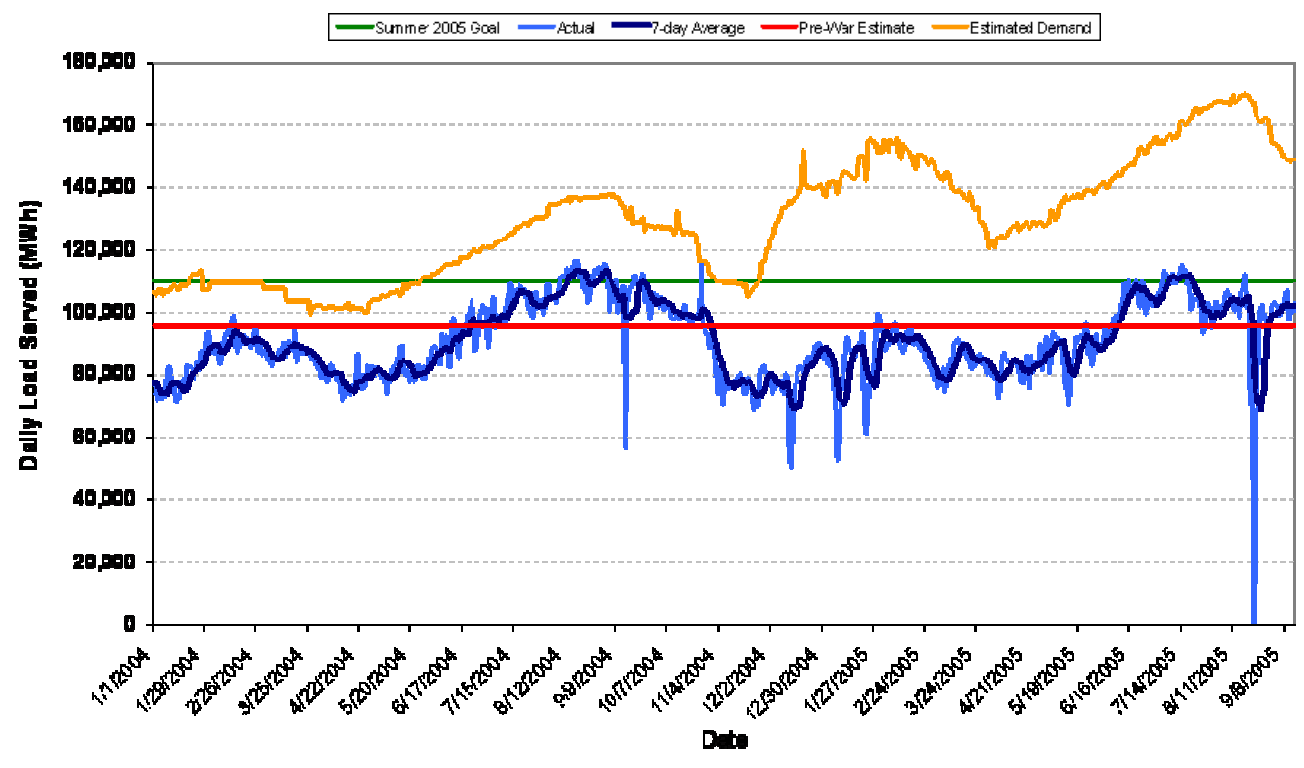

Sorrce: U.S. Deparment of Stas

\section{$\underline{\text { Communications }}$}

The communications sector continues its rapid expansion. The three major cell phone companies continue to enroll subscribers at healthy rates. The Iraq Reconstruction Management Office reports that as of August 31, 2005, there were 3.5 million active cell phone subscribers in Iraq. The number of internet subscribers has increased by $16 \%$ since the last report, a $180 \%$ increase since the U.S. Government began tracking this data. The number of land-line subscribers has been relatively stable since the last report, as Iraqis move to a wireless, rather than a land-based communications system.

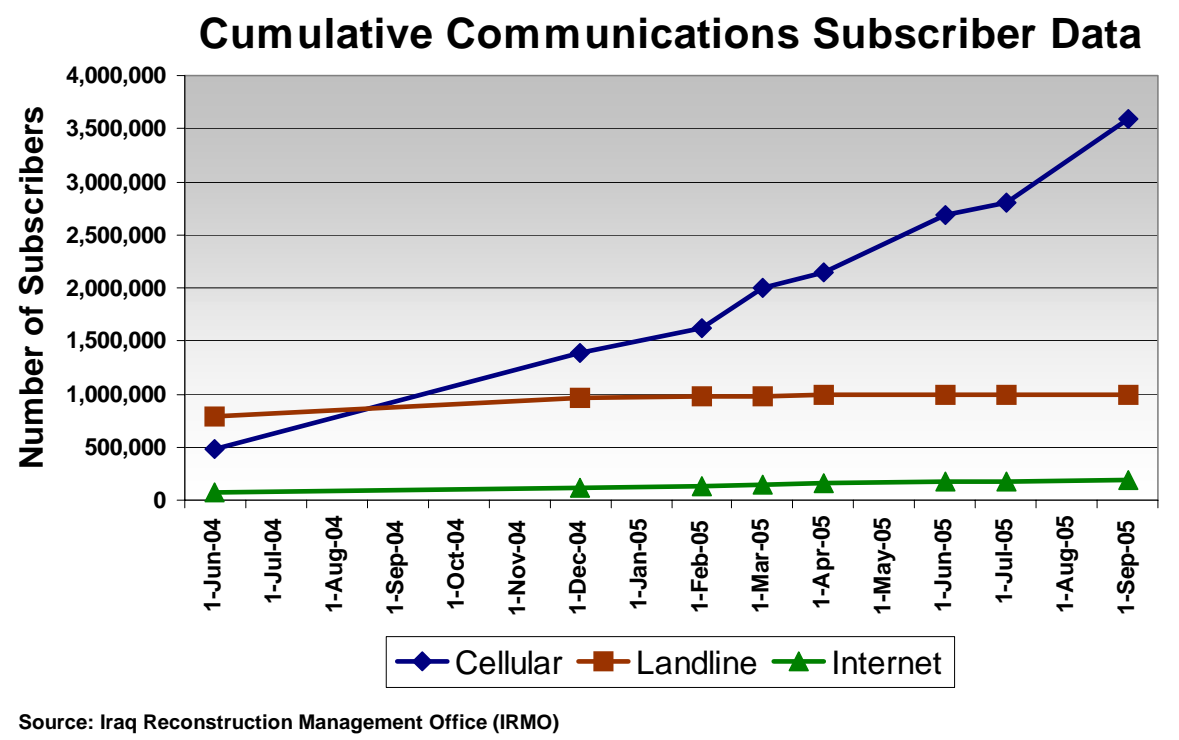


U.S. Government projects continue to support improved communications between Iraqi ministries. Thirty-five government sites in Baghdad have now been connected via the Wireless Broadband Network. This network will promote improved connectivity between ministries.

\section{$\underline{\text { Water }}$}

Through U.S. Government-funded water projects, 22 water treatment facilities have been rehabilitated, with the capacity to serve potable water to 3.1 million people. Additional projects underway will serve an additional 3.7 million people. In an effort to improve access to safe water in rural areas, 68 projects are underway to improve well access. According to the World Bank, $81 \%$ of the population (22.6 million) has access to an improved water source, although delivery of potable water to homes remains unreliable. Access to potable water varies widely among governorates and between urban and rural areas.

\section{Security Environment}

The ultimate goals of the transitional security process remain to defeat terrorists, neutralize the insurgency and transition the Iraqis to security self-reliance. To achieve these goals, the United States, its Coalition partners, and the Iraqi government are focused on objectives that include:

- increasing the capacity of the Iraqi government and its security structures and forces to provide national security and public order;

- neutralizing insurgents’ effectiveness, influence, and ability to intimidate; and

- helping Iraq strengthen rule of law capabilities - law enforcement, justice, and the corrections system.

The Iraqi Security Forces continue to grow in strength and capability with progress documented through indicators that include:

- progress on the program of equipping and training units and individuals of Ministry of Defense and Ministry of Interior forces;

- readiness assessments of operational units; and

- progress in assuming responsibility for security of areas within Iraq.

The Iraqi Security Forces (ISF) continue to assume more battle space and are preparing to assume command and control responsibilities at the division level. At present, the Iraqi Army is in the lead for planning and executing counterinsurgency operations in one Iraqi province that is roughly the size of New Jersey. The ISF also have the lead for 87 square miles in Baghdad and over 450 square miles of battle space in the other Iraqi provinces. Coalition Forces continue to 
support and assist the ISF in these areas as they move towards the capability for independent operations. The ISF patrol alongside Coalition Forces elsewhere in Iraq with growing competence.

More detailed information about the Iraqi Security Forces is presented later in this report.

\section{The Insurgency}

As noted in our previous report, a noteworthy strategic indicator of progress in the security environment is the inability of insurgents to derail the political process or foment widespread ethno-sectarian violence. This is the insurgents' objective, and they are failing to achieve it. Insurgent groups continue, however, to demonstrate an ability to adapt, relocate, regenerate, and sustain a campaign of intimidation against Iraqi officials, professionals, "collaborators with the coalition,” and religious figures.

The insurgency remains concentrated in Baghdad, Ninevah, al-Anbar, and Salah ad Din provinces. In these areas, the insurgency sustains a level of violence and casualties that can produce effects that include: maintaining a non-permissive environment that undermines local governance, emerging institutions, reconstruction efforts, and economic growth; inhibiting foreign investment and diplomatic representation; limiting the roles of non-governmental organizations and contractors; and increasing the costs of reconstruction.

The insurgency is primarily a Sunni Arab phenomenon and is not a national movement; it has a very narrow base in the country. It continues to be comprised of semi-autonomous and fully autonomous groups with a variety of motivations. Measuring the strength of the insurgency in terms of numbers alone does not provide an adequate assessment of insurgent capabilities. Insurgent numbers are a very small fraction of Iraq's population. The vast majority of these groups are connected in some way through members belonging to social networks (e.g., familial, tribal, and former professional) that stretch across Iraq and beyond. Insurgents can also be grouped into several strands: terrorists and foreign fighters, "rejectionists" (mostly Sunni), Saddam loyalists, and criminals.

The main threat to achieving Iraqi control of and responsibility for security in provinces is, in the near and medium term, terrorists and foreign fighters because of the psychological impact on the population of their terror campaign, which appears to target Iraqi civilians indiscriminately. Iraqi rejectionists maintain a steady level of violence that complicates efforts to stabilize Iraq. Criminal elements and corruption often enable the insurgency. As noted, these several strands of the insurgency have failed to derail the political process, and their efforts to foment ethnosectarian conflict have not been successful due in large part to key Iraqi figures calling for restraint among their communities.

Successful elections will not likely change the foreign fighters' strategy. The Iraqi rejectionists particularly those who are Sunni - may, nonetheless, lose some of their support base as the political process advances. Saddam loyalists may present a longer-term threat to building a 
democratic, prosperous Iraq because they remain focused on creating conditions in which they can disrupt and subvert the government.

Multi-National Force-Iraq operations in several of the areas most affected by the insurgency have combined with local commanders' engagement of local officials, tribes, and clerics. These operations have disrupted a number of key insurgent cells, limited their freedom of action, and maintained cooperation with influential local leaders in order to keep reconstruction and democracy-building moving forward. A significant factor enabling progress against the insurgency is the dramatic increase in intelligence tips received from the population in the past several months, indicative of increasing popular rejection of the insurgents.

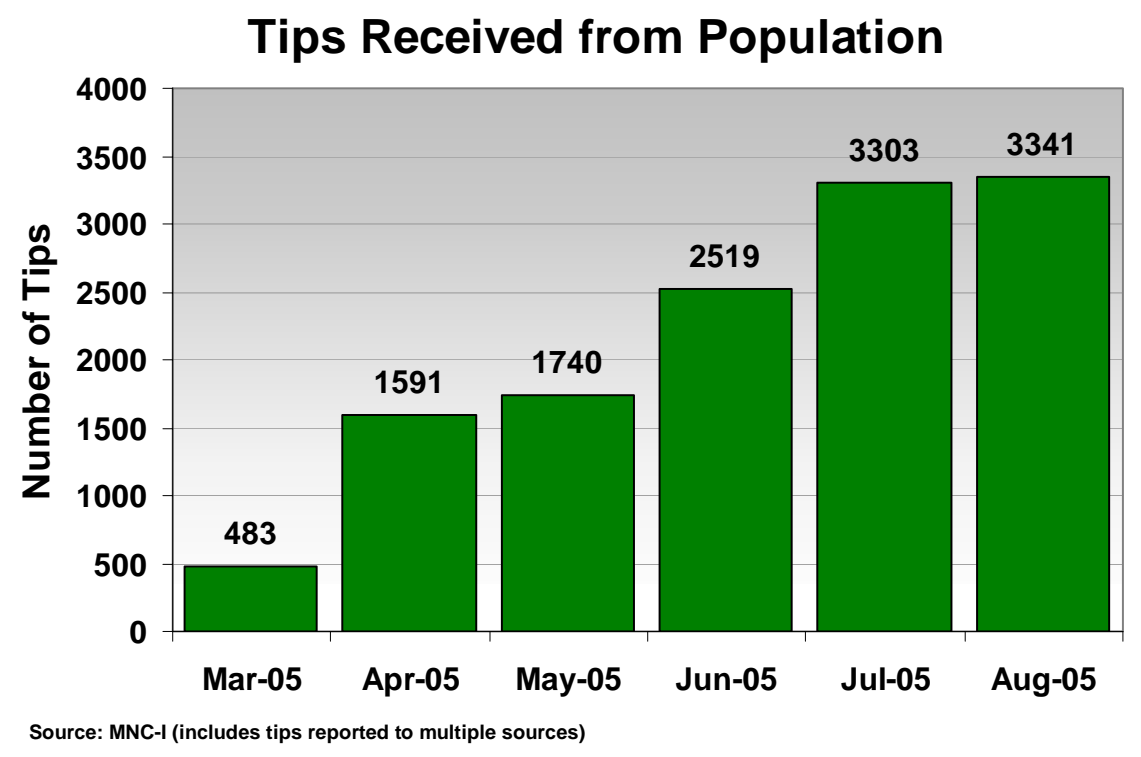

\section{Iraqi Perception of Security}

Iraqis’ perceptions of their security are assessed through various polls.

According to recent surveys, more than three-quarters of those polled in the Kurdish area, MidEuphrates, and South say they feel very safe in their neighborhood and their region. Threequarters of respondents in these regions also say the security situation in Iraq has improved in the last three months.

Iraqis in "Sunni Triangle", however, cities express security concerns. Although half in the Tikrit/Baquba region say they feel very safe in their neighborhood, almost as many feel "not very" or "not safe at all." Three-quarters in Baghdad and eight out of ten Iraqis in Mosul say they do not feel safe in their neighborhood and region. 


\section{How safe do you feel in your neighborhood? \\ [\% by region]}

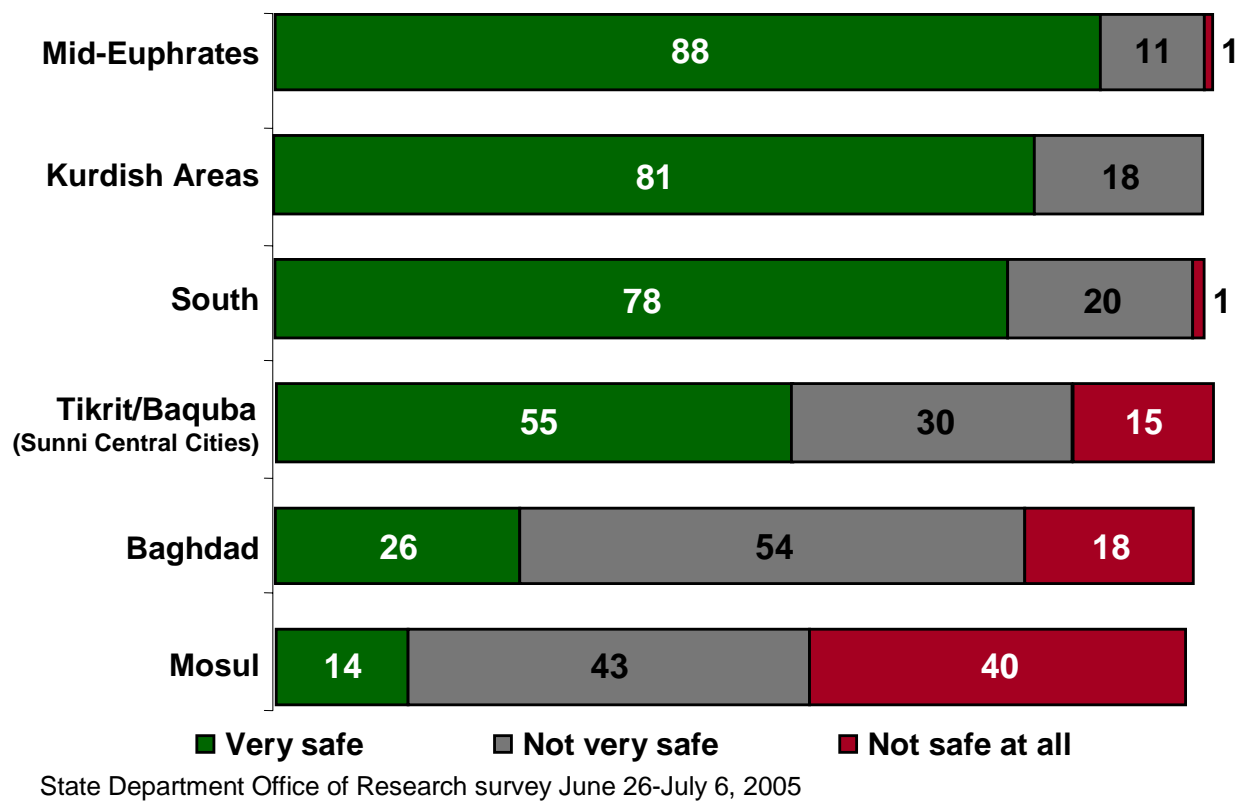

Results are presented in the following areas: Baghdad; Kurdish Areas (Suleymania, Erbil, Dohuk); Mid-Euphrates (Hilla, Najaf, Diwania, Kut, Karbala); the South (Basrah, Nasiriyah, Umara, Samawa); Mosul; and Tikrit/Baquba (Sunni Central cities).

Iraqis continue to express confidence in their security forces, despite insurgent efforts, and want to be protected by them. This is evidenced in polling data and in the willingness of Iraqis to join the security forces despite the obvious risks. Iraqis' attitudes toward their security forces is an important factor in enabling Iraqis to take ownership of their security.

\section{$\underline{\text { Sectarian Conflict }}$}

Creating the perception (and reality) of sectarian violence is a goal of terrorists and some insurgent groups. Terrorist leader Abu Musab Zarqawi has publicly advocated attacks that intensify sectarian tension and has "declared war" on the Shia. There are claims of Shia groups intent on settling old scores with Ba'athists through targeted assassinations, just as Sunni groups are accused of targeting the dominant Shia majority. Similar tensions exist in northern Iraq among the numerous ethnic groups. Although the number of sectarian incidents is very low when compared to total attacks, the brutal methods used, the amount of media coverage these incidents receive, and the risk that increased sectarian violence could eventually escalate into civil war, is cause for serious concern.

Classification of violence as "sectarian" is frequently a matter of perception; it is often difficult to differentiate between attacks on citizens in general (including tribal and local vendettas) and those specifically targeting members of a particular sect. To date, the level of sectarian violence has been relatively localized. Ethno-sectarian attacks may increase, however, as the 
constitutional and electoral process unfolds as a result of insurgent groups' efforts to either shape the election process or derail it by provoking violence across sectarian lines. Iraqis may counter violence with localized protection "militias." Positive statements from religious and political leaders will continue to help dampen violent reactions to such provocations.

\section{Attack Trends}

Insurgent attacks remain concentrated (85\%) in four of Iraq's 18 provinces, containing less than $42 \%$ of the population in mostly urban areas. Twelve provinces, containing $50 \%$ of the population experience only $6 \%$ of all attacks. Six provinces reported a statistically insignificant number of attacks based on population size. The complexity and effectiveness of these attacks vary. They can range from a single insurgent executing an ineffective attack to a coordinated attack with several insurgents using different weapons systems.

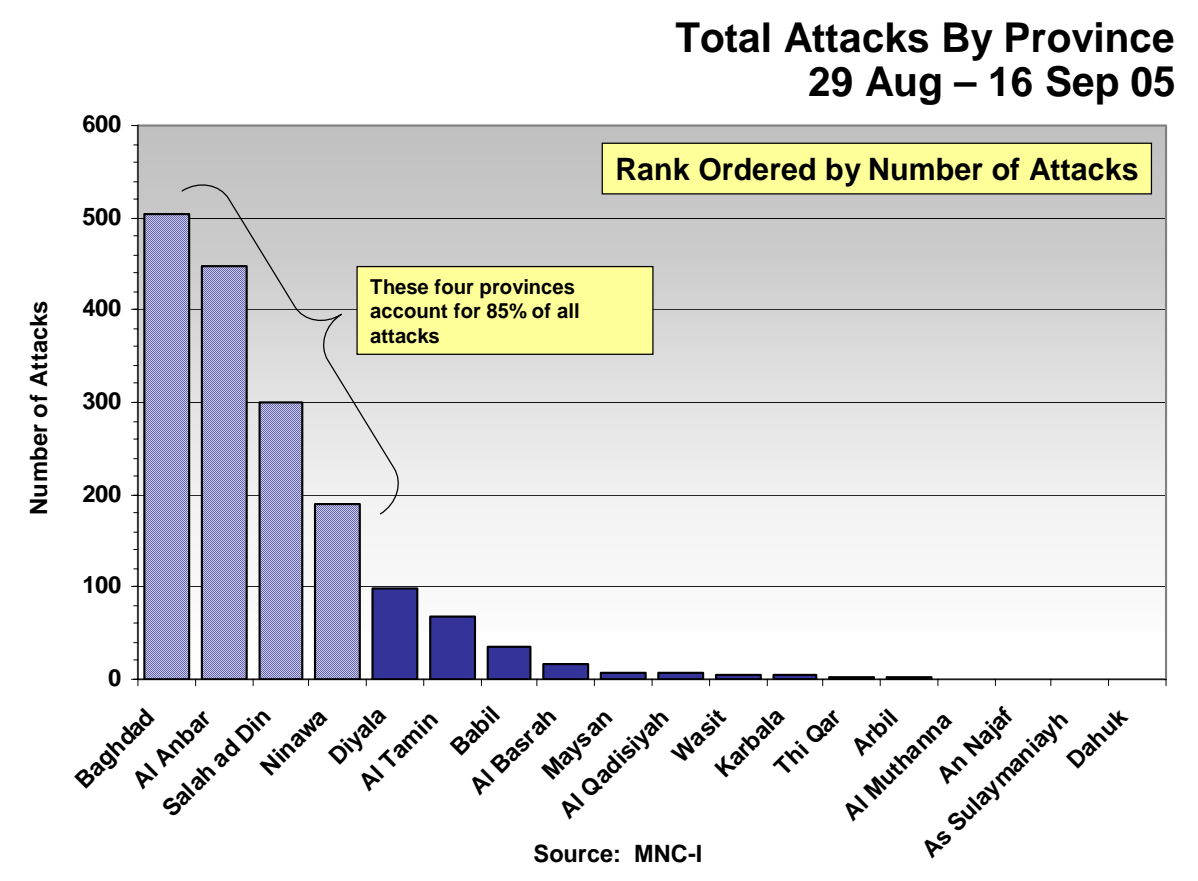




\section{Daily Attacks per Capita By Province}

\section{Aug - 16 Sep 05}

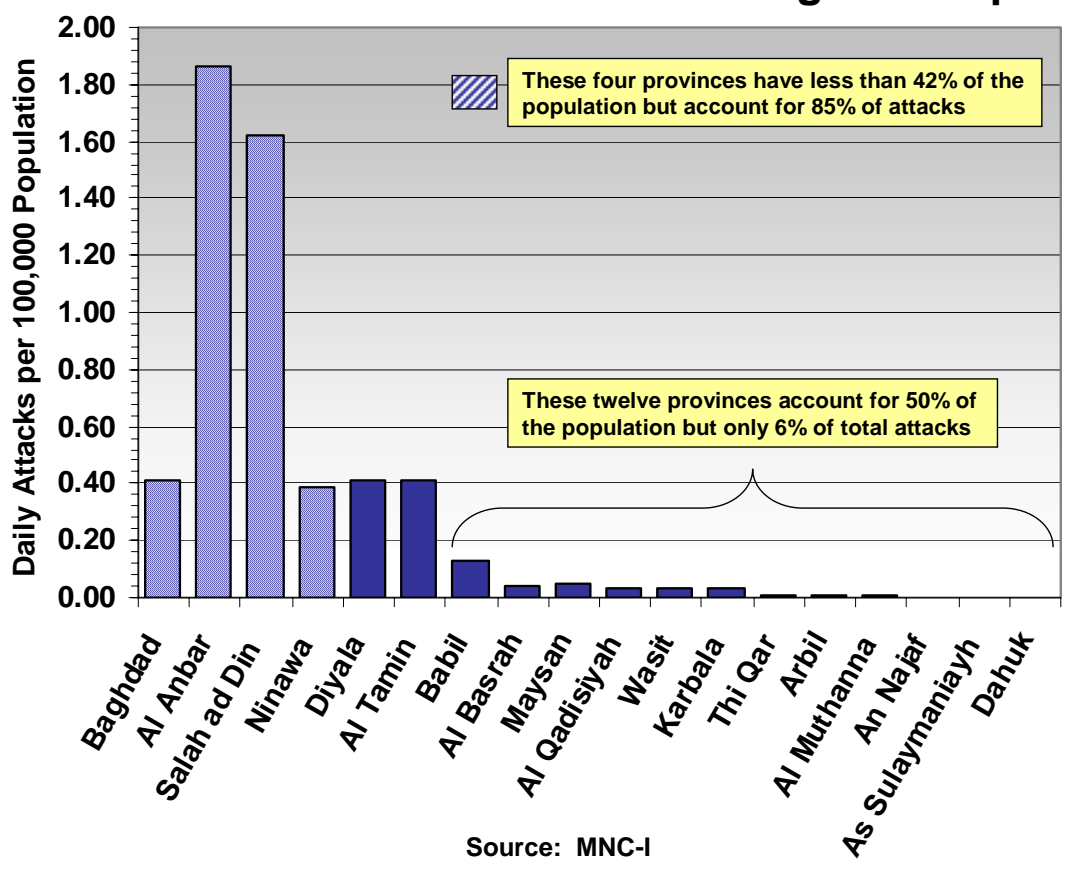

In the run-up to the October constitutional referendum, the weekly average number of attacks has increased, as expected, while insurgents attempt to disrupt the political process. Insurgent attacks against both Coalition Forces and the Iraqi people increased during this reporting period.

\section{Average Weekly Attacks by Time Period 1 Jan $04-16$ Sep 05}

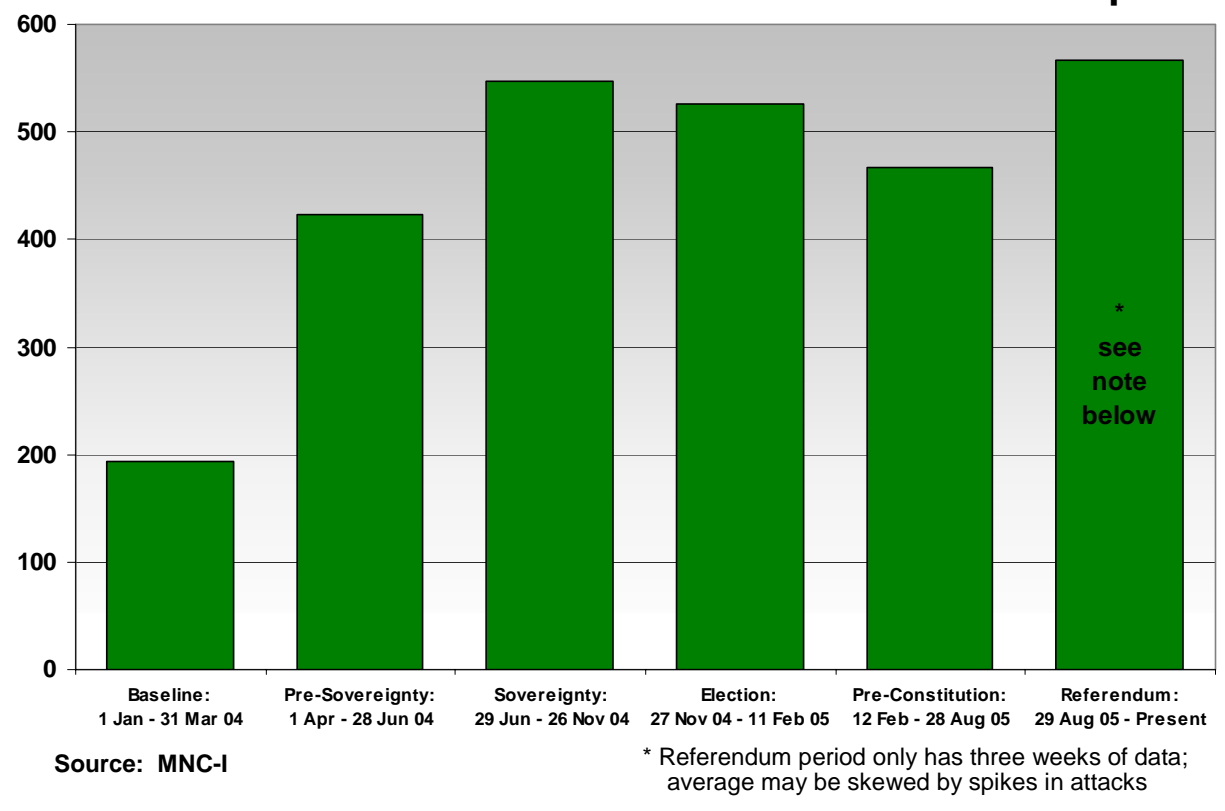


Approximately $80 \%$ of all attacks are directed against Coalition Forces, but $80 \%$ of all casualties are suffered by Iraqis. Insurgents have learned to avoid head-to-head engagements with Coalition Forces, using stand-off or hit-and-run attacks instead. Improvised explosive devices are the primary insurgent method of attack.

\section{Average Daily Casualties - Iraqi and Coalition}

\section{Jan $04-16$ Sep 05}

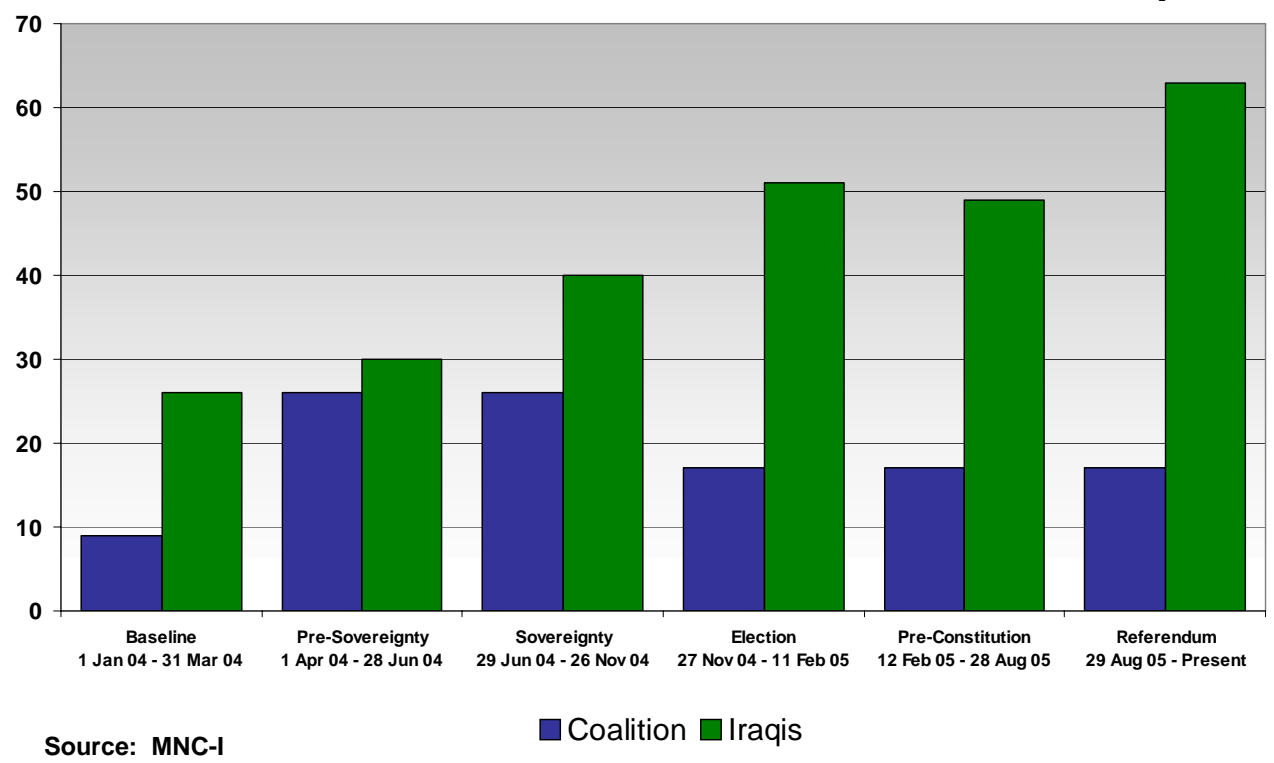

\section{Infrastructure Attacks}

Attacks on Iraq's infrastructure account for an extremely small portion of total attacks, but they continue to have a significant impact on the generation of oil revenue and to heighten public dissatisfaction over essential services, such as electricity and water supplies. Although the number of infrastructure attacks has increased in this reporting period, they remain below the historic highs of 2004. One factor may be the Iraqi government's increased focus on infrastructure security, including the creation of Strategic Infrastructure Battalions. These are discussed in more detail in the Security Forces section. 


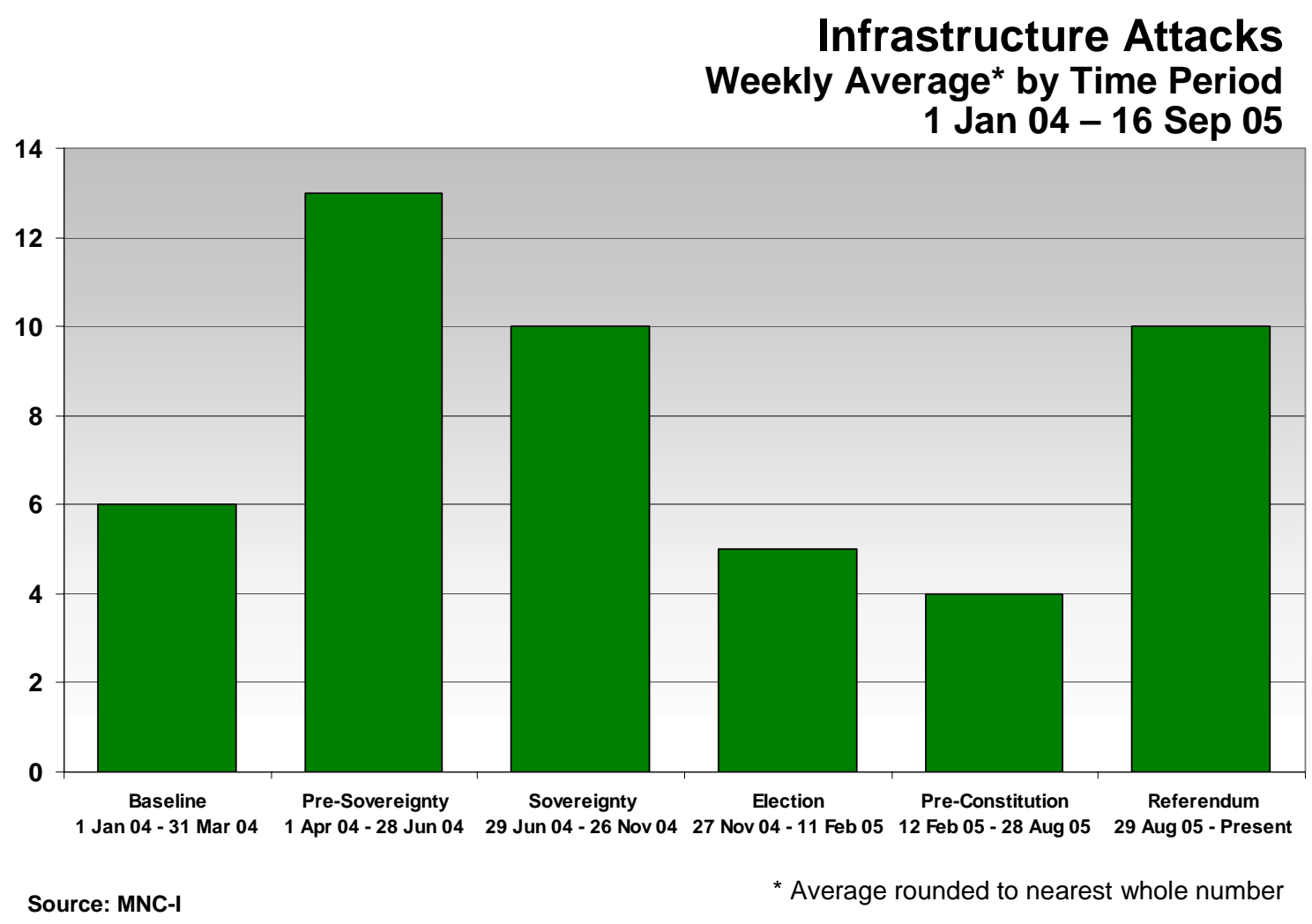

\section{$\underline{\text { Militias }}$}

More than a dozen militias have been documented in Iraq, varying in size from less than a hundred to tens of thousands of members. Some were organized in loose cellular structures, while others had a more conventional military organization. Some were concentrated around a single locale, while others had a more regional footprint. Some of them were wholly indigenous, while others received support such as training, equipment, and money from outside Iraq. Typically, the militias were armed with light weapons and operated as cells or small units.

Even if they do not take up arms against the government, militias can pose a long-term challenge to the authority and sovereignty of the central government. This was the driving force behind the creation of Coalition Provisional Authority Order 91 and the Transition and Re-Integration Committee. For the same reason, Article 27 of the Transitional Administrative Law and Article 9 of the draft Iraqi Constitution prohibit armed forces or militias that are not part of the Iraqi Armed Forces.

The realities of Iraq's political and security landscape work against completing the transition and re-integration of all Iraqi militias in the short-term. Provided the constitution is ratified in October, the government elected in December will have a four-year term of office, and it will have the task of executing the militia-control provisions of the constitution. 
Although it is often referred to as an Iraqi militia, the Jaysh al Mahdi (or "Mahdi Army") of radical Shia cleric Muqtada al Sadr fought Coalition Forces and Iraqi forces in April and August of 2004. The Peshmerga and the Badr Organization are viewed as militias by the Iraqi government and Coalition Forces, while the Mahdi Army is viewed as a potentially insurgent organization.

- Badr Organization. Officially known as the Badr Organization for the Reconstruction and Development, it is the militia of the Supreme Council for the Islamic Revolution in Iran (SCIRI), the largest Shi'ite party in Iraq. It is reported to have links with both Iranian and Iraqi intelligence services and provides protective security for many Shi'ite religious sites as well as religious and secular leaders. Ayatollah Ali al-Sistani is protected by the Badr militia. The Badr Organization has been implicated in the revenge killings of Ba'athists and has also been involved in combat and street fighting with Muqtada al-Sadr's Mahdi Army.

- Peshmerga. The Kurdish Peshmerga trace their origins to the Iraqi civil wars of the 1920s. They fought against the Saddam Hussein regime during the Iran-Iraq war and supported U.S. and Coalition military action in 2003. The Peshmerga groups of the Patriotic Union of Kurdistan (PUK) and the Kurdish Democratic Party (KDP) serve as the primary security force for the Kurdish regional government. The PUK and KDP claim that there are 100,000 Peshmerga troops, and they have insisted on keeping the Peshmerga intact as guarantors of Kurdish security and political self-determination.

- Jaysh al Mahdi. The Mahdi Army of Muqtada al-Sadr engaged in open combat with Coalition and Iraqi forces in April and August of last year, most notably in the battles in and around Najaf. The Mahdi Army has continued to exist after an October 2004 ceasefire agreement, although the Iraqi government has made repeated calls for its disbandment. The exact size of the organization is unknown. There is evidence that they are supplied from sources outside of Iraq, most notably Iran.

\section{Rule of Law Environment}

The most obvious indicator of success in establishing rule of law in Iraq is probably the crime rate. Unfortunately, data on criminal activity in Iraq are unreliable. If such statistics become available, they will be included in future reports.

All 869 judges in Iraq have been reviewed and 135 removed because of substantial evidence of corruption or Ba'ath Party affiliation. All Iraqi provincial criminal courts are also now operational, although the number of trials proceeding in these courts varies. In some areas, relatively few cases are tried. In general, the primary impediment to prosecuting more cases is the ability of police and prosecutors to collect evidence and prepare cases for trial. The Coalition has therefore trained 99 judicial investigators, who in Iraq assume some of the investigative duties performed by detectives in American police departments. Training of Iraqi judges is ongoing, with 351 Iraqi judges having received at least some training. The Coalition has also established a witness protection program and a judicial security program to protect judges and 
courthouses. In addition, the Coalition is engaged in ongoing efforts to build Iraqi prisons and train corrections officers and to encourage the Iraqi government to assume full responsibility for security internees.

The Central Criminal Court of Iraq is the court that tries defendants accused of terrorism and crimes against the Coalition, among other crimes. Since its inception, it has conducted 544 trials and handed down 522 convictions. (Some of the trials involved multiple defendants.)

The Iraqi Special Tribunal (IST) has begun the process of prosecuting Saddam Hussein and other top officials of his regime. Under the Iraqi system, a defendant is given a separate trial for each event that constitutes a crime. Saddam is therefore likely to face multiple, different trials. The first of these trials is currently scheduled to begin on October 19. The U.S. Department of Justice-supported Regime Crimes Liaison Office continues to assist with preparing the IST, providing training and other support for IST attorneys and judges. 


\section{Security Forces Training and Performance}

The United States, its Coalition partners, and the Iraqi government are working together to train, equip, and prepare Iraqi Security Forces to conduct self-sufficient security operations counterinsurgency, border protection, and law and order. Iraq's military and police organizations are making solid progress. Their progress is measured through indicators that include:

- progress on the program of training and equipping units and individuals of the Ministry of Defense and the Ministry of Interior and forming them into operational units;

- readiness assessments of operational units' capabilities; and

- progress in assuming responsibility for security of areas within Iraq.

As of September 19, 2005, 116 ground combat battalions of Iraqi military and Special Police Forces are conducting operations against the insurgency, an increase of 22 over the past three months. Over 192,000 Iraqis have been trained and equipped as members of the police and military forces. This is an increase of approximately 21,000 personnel over the number reported in the previous report and represents a key indicator of the progress made in development of the Iraqi Security Forces (ISF). The criteria for withdrawing Coalition Forces from Iraq remain conditions-based, but one key condition - fielding of capable ISF - is continuing apace. Another necessary development is the growth of required capabilities within the security ministries, including procurement, life support contracting, and personnel management. The U.S. EmbassyIraq and the Multi-National Force-Iraq recently agreed to assign the mission of developing security ministry capabilities to the Multi-National Security Transition Command-Iraq (MNSTCI) effective October 1, 2005. The military expertise, unity of effort, and added resources inherent in this change will help in producing capable security ministries.

\section{Current Status of Trained and Equipped Iraqi Security Forces}

Ministry of Defense Forces ${ }^{*}$
\begin{tabular}{|c|c|}
\hline COMPONENT & OPERATIONAL \\
\hline ARMY & $\sim \mathbf{8 6 , 9 0 0}$ \\
\hline AIR FORCE & $\sim \mathbf{2 0 0}$ \\
\hline NAVY & $\sim \mathbf{7 0 0}$ \\
\hline TOTAL & $\mathbf{2 7 , 8 0 0}$ \\
\hline
\end{tabular}

Ministry of Interior Forces**

Total Trained \& Equipped ISF:

Data as of 19 sep $05 \quad \sim 192,100$

\begin{tabular}{|c|c|}
\hline COMPONENT & $\begin{array}{c}\text { TRAINED \& } \\
\text { EQUIPPED }\end{array}$ \\
\cline { 1 - 1 } POLICE & $\sim 68,800$ \\
\cline { 1 - 1 } $\begin{array}{c}\text { HIGHWAY } \\
\text { PATROL }\end{array}$ & $\sim 68,800$ \\
\cline { 1 - 2 } $\begin{array}{c}\text { OTHER MOI } \\
\text { FORCES }\end{array}$ & $\sim 35,500$ \\
\hline TOTAL & $\sim 104,300$ \\
\hline
\end{tabular}

Note: Numbers in this report are estimates derived from reports provided by Iraqi Security Forces.

*Ministry of Defense Forces: Absent Without Leave (AWOL) personnel are not included in these numbers. Unauthorized absences are no longer impacting operations. The Army component includes the operational totals of the combat battalions, special operations forces, combat support/combat service support/training units, and the Strategic Infrastructure Battalions.

**Ministry of Interior Forces: Exact Absent Without Leave (AWOL) personnel numbers are unknown. However, embedded Special Police Transition Teams (SPTTs) and the Police Partnership Program (P3s) are gaining better fidelity on MOI present for duty status. As a result, all known police AWOL and causalities have been dropped from the rolls and are not included in these numbers. 
The Iraqi government continually assesses its force requirements based on current threat. The government currently projects an end-state combined total force structure for the Ministry of Defense (MOD) and the Ministry of Interior of 325,000 - an increase of about 28,000 since the previous report, mainly because of an increase in authorized army and combat service support personnel at MOD - and plans to complete total force generation by August 2007.

As the operational environment changes and the Iraqi Transitional Government transitions into the constitutional Government of Iraq, so will the plan for security forces evolve. The force generation program maintains the flexibility to adapt to changing requirements. Both the military and police forces will need to evolve as the insurgency is defeated. The force structure provides for eventual conversion to a more conventional structure in which the military focuses on external security and police forces provide internal security.

\section{Readiness of Iraqi Security Forces}

A key measure of progress is the growth in the number of operational units and in the percentage of these units capable of taking the lead in combat operations. Iraqi units are assessed at different levels of readiness. Units at level four are forming - that is, training - and are not considered operational.

Units in the top three levels are all operational - that is, capable of (and frequently engaged in) combat operations against the enemy. Units at level three are fighting alongside Coalition units. Level two units are "in the lead" - this level is the critical achievement that marks the point at which the unit can take over its own battle space. Units at level two can control their own areas of responsibility and, therefore, allow Coalition units to focus elsewhere.

The final level is the one at which the unit is fully independent - not just capable of leading operations but requiring no Coalition assistance in any form. Considering the need for further development of Iraqi logistical elements, ministry capacity and capability, intelligence structures and command and control, it will take some time before a substantial number of units are assessed as fully independent and requiring no assistance.

Levels of readiness for Iraqi units are evaluated by embedded Coalition teams using the Transition Readiness Assessment (TRA) process described in the July report. The TRA began less than a year ago and assesses objective as well as subjective measurements of key variables in unit readiness including leadership, command and control, personnel, equipment, training, and sustainment. These variables may change over time - just as is the case for U.S. units - as key personnel rotate, equipment is added or replaced, unit operations tempo changes, and so forth. As changes occur, especially those which occur in a hostile environment, the assessed level of readiness will change as well.

The following charts depict the capability of MOD units and MOI “military-type” units assessed using the TRA. The number of MOI Special Police Forces units operating "in the lead with Coalition support or fully independent” reflects a re-baselining of MOI Special Police Forces that took place in June 2005. At that time, embedded Special Police Transition Teams (SPTTs) joined these MOI units and began assessing their effectiveness in accordance with the TRA. All of the 28 MOI authorized Special Police Force battalions are trained, equipped and in the fight. 
More importantly, the MOI table does not include 67,500 trained and equipped individual Iraqi Police Service (IPS) personnel throughout Iraq.

\section{Estimated MOD Forces Capabilities}

\begin{tabular}{|l|c|c|}
\hline \multirow{2}{*}{ COMPONENT } & \multicolumn{2}{|c|}{$\begin{array}{c}\text { IRAQI UNITS ACTIVELY CONDUCTING } \\
\text { COUNTER INSURGENCY OPERATIONS }\end{array}$} \\
\cline { 2 - 3 } & $\begin{array}{c}\text { Battalions Fighting Side } \\
\text { by Side with Coalition } \\
\text { Forces }\end{array}$ & $\begin{array}{c}\text { Battalions in the Lead with } \\
\text { Coalition Support or Fully } \\
\text { Independent }\end{array}$ \\
\hline $\begin{array}{l}\text { Iraqi Army and Special } \\
\text { Operation Combat Forces }\end{array}$ & 52 & 36 \\
\hline & \multicolumn{2}{|c|}{$\begin{array}{c}\text { IRAQI UNITS ACTIVELY SUPPORTING } \\
\text { COUNTER INSURGENCY OPERATIONS }\end{array}$} \\
\hline $\begin{array}{l}\text { Combat Support, Combat } \\
\text { Service Support and } \\
\text { Training Units }\end{array}$ & 2 & 3 \\
\hline Air Force & \multicolumn{2}{|c|}{3} \\
\hline Navy & 0 & 2 \\
\hline
\end{tabular}

Data as of: 19 September 05

\section{Estimated MOI Special Police Forces Capabilities}

\begin{tabular}{|l|c|c|}
\hline \multirow{2}{*}{ COMPONENT } & \multicolumn{2}{|c|}{$\begin{array}{c}\text { IRAQI UNITS ACTIVELY CONDUCTING } \\
\text { COUNTER INSURGENCY OPERATIONS }\end{array}$} \\
\cline { 2 - 3 } & $\begin{array}{c}\text { Battalions Fighting Side } \\
\text { by Side with Coalition } \\
\text { Forces }\end{array}$ & $\begin{array}{c}\text { Battalions in the Lead with } \\
\text { Coalition Support or Fully } \\
\text { Independent }\end{array}$ \\
\hline Public Order Battalions & 12 & 0 \\
\hline Mechanized Battalions & 2 & 1 \\
\hline $\begin{array}{l}\text { Special Police } \\
\text { Commando Battalions }\end{array}$ & 12 & 0 \\
\hline $\begin{array}{l}\text { Emergency Response } \\
\text { Unit }\end{array}$ & 0 & 1 \\
\hline
\end{tabular}

For conventional police forces, transition readiness has not yet been assessed. Data as of: 19 September 05

\section{Iraqi Security Forces and the Iraqi Constitutional Referendum}

It should be noted here that the Minister of the Interior (MOI) has responsibility for the security planning for the October 15, 2005, constitutional referendum. As in the January 2005 elections, Iraqi Security Forces (ISF) have the principal responsibility for providing security for the referendum. Iraqi police station commanders at the provincial level are responsible for polling 
center security, while forces of both the Ministry of Defense and Ministry of the Interior special police will be providing security outside the polling centers.

The total number of ISF today exceeds the number that was available for the successful January 2005 elections by some 60,000. There are 6,235 polling centers, up from 5,677 polling centers in the January elections. Coalition Forces will assist with broad area security.

\section{Progress of Iraqi Security Forces}

Much has been made about the observation that only one Iraqi MOD battalion is at level one fully independent, not just capable of leading operations. Coalition Forces are helping Iraqis not just build combat elements but establish all the supporting infrastructure needed to sustain them - materiel, logistics, doctrine, command and control, and other functions. Development of Iraqi units takes place in the midst of an insurgency, with the enemy actively attempting to disrupt the re-establishment of the Iraqi Security Forces (ISF), destroy their infrastructure and equipment, and intimidate recruits. In this context, the progress of the ISF is truly remarkable; even some U.S. allies would not be able to meet level one standards because they do not have the enablers they need to operate fully independently.

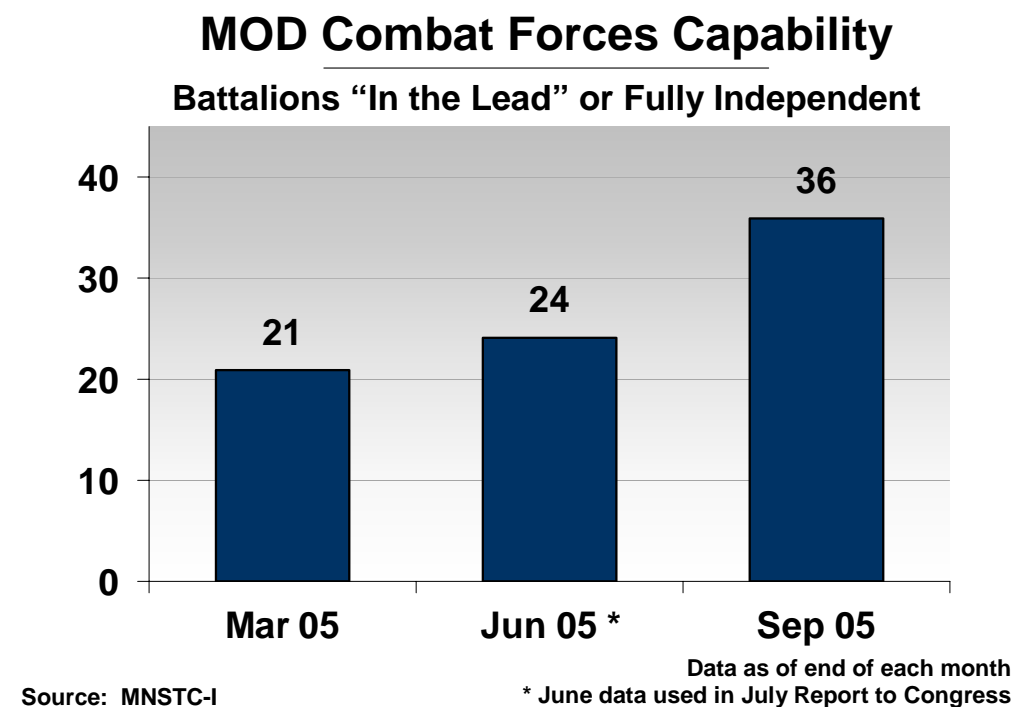

Progress also needs to be seen through a wider aperture. The more accurate measure of progress is Iraqi units in the lead - planning and successfully executing counterinsurgency operations, with minimal direct support or assistance of Coalition Forces. It is at level two that Iraqi units can take their own battle space, and it is at that level - where there has been steady progress that the Coalition is focusing current efforts.

This progress in Iraqi Security Forces development is apparent on the ground. Iraqi battalions of the 3d Iraqi Division, the Border Force, and the Police Commando Division were operating in northwestern Iraq during recent combat operations in and around Tal Afar. Iraqi battalions from several different divisions - police and army - are also fighting in Anbar province with Coalition 
Forces. Additionally, an Iraqi Police Mechanized Battalion is assisting coalition forces in securing the airport road, and three Iraqi battalions now secure a major thoroughfare in Baghdad (Haifa Street). Iraqi security forces have responsibility for the holy cities of Najaf and Karbala and other locations.

\section{Iraqi Ministry of Defense Forces}

The Ministry of Defense (MOD) forces' mission is to defend Iraq against external threats and assist in providing defense against internal threats to national security. The MOD was created in early 2004, and the number of fielded Army combat battalions has increased from zero to 88 which includes two special operations battalions - plus several support battalions in only 18 months.

\section{Iraqi Army Combat Battalions in the Fight}

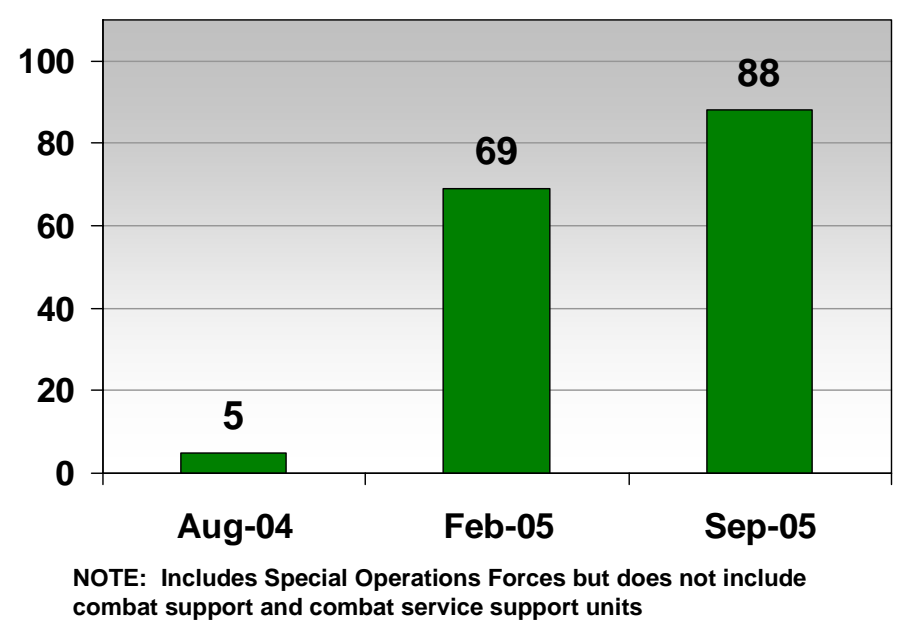

Iraqi units are being fully integrated into all major Coalition operations and are playing a key role in fighting the insurgency. This role includes stabilizing and restoring government control to areas after combat operations, such as in Tal Afar. Thus, they are performing numerous missions that otherwise would be done by U.S. or other Coalition Forces. MOD forces also include a small Air Force and a small Navy, including a naval infantry element that will assume missions from Coalition Forces.

MOD continues to generate combat units, but it is increasingly focused on developing combat enablers and logistics support units that enable fully independent operations. Current projections foresee MOD force generation complete by late 2006. Projected end-strength is approximately 131,000. Equipping of these forces continued, using U.S.-funded procurements. In the past quarter, MOD forces received over 10,000 AK-47 rifles, almost 1,800 pistols, over 2,700 light and medium machine guns, and over 750 light and medium vehicles. Although the July report stated the Iraqi Army had more than 100\% of AK-47 requirements, the Army had an additional requirement due to an increase in authorized end-strength. 
The Ministry of Defense continued to take over more training functions from the Coalition in recent months, including three Regional Training Centers, and is now in charge of the Iraqi Army Service and Support Institute (formerly the Combat Service and Support School), the Military Intelligence School, the Military Police School, and the Engineering School. These Iraqi-led schools and training centers will provide the means for the Iraqis to continue improvements in their ability to provide tactical logistical support and combat enablers to the combat battalions.

\section{$\underline{\text { Army }}$}

The 86 Iraqi Army combat battalions now conducting counterinsurgency operations include almost 75,000 trained and equipped soldiers organized into nine infantry divisions and one mechanized division; an additional 12,000 troops provide support, training and special security functions. An indicator of progress in the Iraqi Army is its recent involvement in the counterinsurgency operation "Restoring Rights" in Tal Afar. In this operation, eleven Iraqi combat battalions (a mixture of military and police forces) were employed as independent maneuver elements within their own assigned battle space. This is an improvement from operation "alFajr" in Fallujah late last year, where five Iraqi combat battalions participated, following behind Coalition Forces to occupy ground secured by the Coalition. In Tal Afar, Iraqis led tribal engagement, humanitarian assistance, and reconstruction and were partnered with Coalition Forces for public relations and establishing security. Although no exact comparison can be made between the two battles, the Iraqi populace was a key enabler of the reduction in friendly and civilian loss of life during the fighting.

Development of complementary combat support and combat service support continues at the tactical and operational levels. A multi-layered logistics system has been designed, was approved by the Multi-National Force-Iraq and the Ministry of Defense (MOD) in early 2005, and is being built. The system consists of national-level supply contracts, regional and local base support units, motor transport regiments in each division, and headquarters and services companies in each combat battalion. Because MOD does not yet have organic maintenance capability, MNSTC-I has implemented an interim national maintenance contract.

The Army is equipped primarily with Warsaw Pact weapons, either donated by NATO or other nations, or purchased by the Ministry of Defense (MOD) or the Multi-National Security Transition Command-Iraq. Some important equipment additions in the past three months include hundreds of Kraz and Gaz trucks (Russian manufacture, purchased by MOD) and hundreds of heavy machine guns. The costs of sustaining the Army's equipment may require the Iraqis to spend significantly more money than they anticipated on maintaining the force structure they want.

Training of individual military recruits follows one of two patterns. Recruits with former military experience can go into a Direct Recruit Replacement program. The Multi-National Force-Iraq Major Subordinate Commands train these recruits following a three-week program standardized by MNSTC-I. Recruits without military experience are sent to a program conducted under MNSTC-I auspices at the Iraqi Training Brigade in Kirkush. All new recruits 
undergo the same five-week program of instruction and then receive an additional three-to-seven weeks of training, depending on their military occupational skill assignment. The specialized training develops skills in supply, communications, administration, armor, transportation, maintenance, and military police, among others.

Leadership of Iraqi Army units is assessed regularly as part of Transition Readiness Assessments. Some units excel because they have leaders who are extremely proficient combat veterans; the majority of units have leaders of varying degrees of proficiency.

Absenteeism in the Iraqi military is dependent upon where a unit falls in its training and employment life cycle. During individual and collective training, some recruits determine that the life of a soldier is not for them and leave, while others fail to meet training course standards and are dismissed. Approximately 15\% attrition is the norm for initial training. When a unit is fully trained and employed in combat operations, some soldiers find that they do not like the particular location, or they find that the danger of the counter-insurgency is too much for them. In either event, Iraqi Army policy is that soldiers who leave are dropped from the rolls within a week and are prohibited from ever rejoining the Iraqi Security Forces (ISF). What remains is a unit that is confident in its ability to fight, in its leaders, and in its backup (which is increasingly another Iraqi unit). Although deployments to combat sometimes cause absentee spikes of $5 \%$ to $8 \%$, soldiers in units in this final stage of development are unlikely to leave the service; absent without leave (AWOL) rates are typically about $1-4 \%$ for most divisions. As more and more ISF are generated, absenteeism has become less of a problem.

Recruiting for the Iraqi Security Forces (ISF) continues to be done through national recruiting centers spread throughout the country. The Sunni community is a major focus of recruiting efforts. Sunni enlistments have increased since Sunni religious and political leaders have started expanding their participation in the political process. The goal remains a diversified force that represents national ethnic and religious demographics and whose allegiance is to the Republic of Iraq rather than to a particular ethnic, religious, or tribal group. All recruits sign a contract agreeing to serve anywhere in Iraq based on mission requirements. The enlistment oath is being revised to include swearing loyalty to the Iraqi constitution.

Some insurgent infiltration of ISF undoubtedly occurs, both through the recruitment process and through bribery and intimidation. Although it is reasonable to believe that it would be more prevalent in Sunni-majority provinces, the precise extent of such infiltration cannot be known. The inability of suicide bombers to penetrate police and military facilities regularly is an encouraging indicator. Greater vetting of recruits makes infiltration more difficult. More detailed information in insurgent infiltration is contained in the classified annex.

Military Transition Teams (MiTTs) are embedded with every Iraqi battalion, brigade and division and assess units using the Transition Readiness Assessment; these assessments identify overall unit capabilities including the quality of leadership and unit weaknesses. In addition, the presence of the MiTTs helps the Ministry of Defense forces monitor the risk of insurgent infiltrations. 


\section{Iraqi Special Operations Forces}

Iraqi Special Operations Forces (ISOF) include approximately 1,300 trained and equipped soldiers organized into a single brigade with two battalion-sized operational units: the Iraqi Counter-Terrorism Task Force and the Iraqi Commandos. A Special Operations Support Battalion and Special Operations training organization have also been activated. The latter two are currently at Initial Operating Capability, providing only limited capabilities, but will develop into integral enablers of ISOF missions.

The Commandos and the Iraqi Counter-Terrorism Task Force have conducted frequent reconnaissance and direct action missions throughout the most hostile and non-permissive areas in Iraq, to include numerous recent operations in al-Anbar province, participation in Operation Restoring Rights in Tal Afar, and several precision raids conducted in and around Baghdad. On every occasion, the ISOF has proved to be one of the most highly trained, reliable, and effective Iraqi units.

The ISOF operates primarily with U.S. equipment to enhance interoperability with U.S. Special Forces, sustainability, and the long-term bilateral working relationship. This equipment includes the M4 carbine, M240 machine gun, M2 .50 caliber heavy machine gun, and High Mobility Multi-purpose Wheeled Vehicles (HMMWVs). Fielding of individual equipment continued during the past quarter, as did fielding of eight M113 Armored Personnel Carriers (APCs). Although the ISOF is fully equipped for combat operations, they still lack the organic ground and air mobility assets necessary for rapid deployment throughout the country.

There were no major changes in the past three months in the training program for ISOF. All ISOF continue to undergo careful pre-training screening/vetting and extremely rigorous training. The success of the ISOF in combat operations is directly attributed to their comprehensive training program. Completion of ranges and barracks at unit locations will facilitate more effective training and command and control.

Leadership of ISOF is assessed monthly with the Transition Readiness Assessment system. Senior leadership is assessed as generally strong, as is the junior leadership. Absent without leave (AWOL) rates in ISOF are insignificant.

\section{Strategic Infrastructure Battalions}

In early 2005, the Iraqi Transitional Government directed the formation of four Strategic Infrastructure Battalions (SIBs) to protect critical oil pipelines and eventually to protect parallel electrical transmission lines. Ministries that own critical infrastructure are currently responsible for providing security for their facilities. They use a mix of their own ministerial guard forces and contracts with local tribal forces. Coalition forces provide security in some instances as well.

Since the July report, the SIBs have been integrated into the Ministry of Defense (MOD) force generation plan and are built on the standard Table of Organization and Equipment for an Iraqi infantry battalion. Training of these battalions utilizes a "train the trainer" model: Iraqi 
instructors are first trained; these instructors are then responsible for training of their individual companies. The first four SIBs are manned and will complete unit training in mid-October. MNSTC-I is providing mission-essential equipment to the SIBs, such as AK-47s, vehicles, Individual Body Armor, helmets and uniforms. The Iraqi government has begun fielding up to seven more SIBs, bringing the total authorized to eleven with a possible end-state total of 17 or more SIBs, but they are minimally equipped and untrained. MNSTC-I has agreed to match MOD-provided funding up to $\$ 35$ million to fund start-up costs for the first four SIBs. Training for all SIBs will follow the same model. The SIBs are being assessed using the Transition Readiness Assessment system.

Navy

The Iraqi Navy is executing operational missions that include border and waterway protection from smuggling and site protection of port and oil assets in the Gulf. The Navy currently has over 700 trained and equipped sailors and Marines organized into two squadrons.

It is anticipated that the Iraqi Navy will assume point defense responsibilities for the offshore oil terminals. Coalition military and civilian advisors will work closely with the Ministry of Defense (MOD) to ensure it has the capacity to handle this transition. The Iraqi Navy's ability to conduct planned operations with Coalition partners has suffered as a consequence of a lack of MOD funding and contracting execution capability for fuel, and an ongoing inability to provide sufficient spare parts and maintenance, resulting in operational missions being cancelled. Iraqi Marines are continuing their manning of oil platform defense stations under the guidance of U.S. Navy advisor training teams.

The Iraqi Navy operates five Predator Class Patrol Boats (PB), 24 Fast Aluminum Boats (Dual Outboard Engines), and ten Rigid Hull Inflatable Boats. The naval forces are further equipped with various small arms and Night Vision Devices. Current planning calls for the Iraqi Navy to be equipped with three al-Faw class patrol boats by December 2005 and with an additional three by September 2006. Design deficiencies (e.g., seawater strainers below the waterline) and construction shortcomings (e.g., poor welding) of the one Al Faw boat already delivered are causing significant delays in fielding these patrol boats. Funding for two Off-Shore Support Vehicles has still not been provided, affecting the Navy's capability to support itself in maritime operations.

The Iraqi Navy Training Department continues to conduct all of its own training, assisted by the advisory support team. Training is focused on maintaining basic seamanship skills and on maritime patrol operations. Leadership of the Iraqi naval forces is assessed through the Transition Readiness Assessment system. Senior commanders are generally strong, although weak staffs inhibit their effectiveness. A strong group of junior officers provides a foundation for future naval leadership. The absent without leave (AWOL) rates in the Iraqi Navy are insignificant. 


\section{$\underline{\text { Air Force }}$}

The Iraqi Air Force has more than 200 trained and equipped personnel. A squadron of three C$130 \mathrm{E}$ aircraft operates regularly from Ali Air Base. The squadron supported the recent counterinsurgency operation in Tal Afar by transporting Iraqi Army soldiers and commandos to Tal Afar in late August and early September. The Ministry of Defense (MOD) still has not concluded a Foreign Military Sales (FMS) program to sustain the C-130E fleet, resulting in MNSTC-I continuing to fund operations and maintenance costs. Resolution of the FMS case remains an issue that MNSTC-I regularly addresses with the MOD.

The Iraqi Air Force also operates a fleet of small reconnaissance aircraft: two Seekers, six CompAir aircraft, and six CH-2000s. The Seeker and the CompAir aircraft are flying reconnaissance missions daily. The six $\mathrm{CH}-2000$ aircraft are currently grounded for engineering deficiencies. A lack of Ministry of Defense funding limits fuel and spares for the reconnaissance aircraft. The Iraqi Air Force also operates five Bell Jet Ranger helicopters. These aircraft are used for training purposes only. The helicopter fleet also includes four donated UH-1 helicopters in Iraq. Another twelve are being held by Jordan awaiting final decision by the Iraqi Air Force on conversion to Huey Two, a version more capable of operating in the Iraqi environment. None of the UH-1 aircraft in the Iraqi Air Force are currently operating, because of maintenance problems.

Training for the Iraqi Air Force consists of pilot sustainment and conversion training. Maintenance training is also being accomplished. All training is provided by the Coalition Air Advisory Support Team. Iraqi pilots generally have many hours of flight time, but tend to be senior officers. A system of recruiting and developing junior pilots needs to be developed. Leadership of the Iraqi Air Force is still being developed and is formally assessed using the Transition Readiness Assessment system.

\section{$\underline{\text { NATO Training Mission }}$}

The NATO Training Mission in Iraq (NTM-I) is helping to build the Iraqi Security Forces with training and advisory support to middle- and senior-level leaders at locations such as the National Joint Operations Center, Ministry of Defense Headquarters Joint Operations Center, and the Iraqi Staff College. A key role of the NTM-I is to assist in the development of the new Staff College. As noted earlier in this report, NTM-I completed instructor training for 24 Iraqis in July 2005. The class included nine Iraqi colonels and 15 lieutenant colonels. A Senior Joint Staff College course, similar to a command and general staff curriculum, has a planned duration of approximately nine months. A seven-month junior course has been developed for officers who have attained the rank of captain or major. Eighty-eight Iraqi students started pilot Joint Staff College courses on September 25. 


\section{$\underline{\text { Iraqi Ministry of Interior Forces }}$}

The Ministry of Interior (MOI) forces consist of the Iraq Police Service (IPS), Special Police (Police Commandos, Public Order Police, and the Mechanized Police), the Emergency Response Unit, Border Forces, the Highway Patrol, and Dignitary Protection. Current projections foresee MOI force generation complete by August 2007. Projected end strength is approximately 195,000. In the past quarter, MOI forces received more than 21,000 AK-47 rifles, almost 15,000 pistols, and more than 1,700 light and medium machine guns. They were also issued more than 1,900 light and medium vehicles. Individual MOI personnel received almost 19,000 sets of individual body armor and more than 10,000 Kevlar helmets.

Insurgent infiltration is likely a more significant problem in Ministry of Interior forces than in Ministry of Defense forces. Because the police are often recruited by local police chiefs with little Coalition oversight, infiltration tends to be somewhat higher in the police than in the military and paramilitary forces. Although infiltration harms the ability of the police to combat the insurgency, it does not render the forces incapable. The exact extent of insurgent infiltration is unknown at this time; the topic is addressed further in the classified annex.

\section{$\underline{\text { Iraqi Police Service }}$}

The Iraqi Police Service (IPS) is the primary organization for local civilian policing in Iraq, analogous to "beat cops" in the United States. Their mission is to enforce the law, safeguard the public, and provide internal security at the local level. The police are organized into patrol, station, and traffic sections in all major cities and provinces in Iraq. Iraqi citizens are becoming more comfortable making direct contact with the IPS to report local crime, although a local "tips" hotline remains popular because of the anonymity it provides. The IPS continues to improve in performance and professionalism, increasingly using appropriate methods and developing consistency in law enforcement.

\section{Training}

A total of 67,500 IPS have been trained and equipped, an increase of 5,500 in the three months since the last report. MNSTC-I is currently behind in its projection to train and equip 75,000 IPS by the October 15 referendum; however, MNSTC-I estimates that it will reach its full-authorized complement of 135,000 IPS by February 2007. Training of Iraqi police continues at the Jordan International Police Training Center and the Baghdad Police College, complemented by seven smaller regional academies. The police training curriculum was recently increased significantly, effectively adding two full weeks of training to the previous eight-week course. To date, more than 44,400 police recruits have completed the eight-week basic police training. As mentioned in the last report, new police academy graduates receive informal mentoring from veteran Iraqi police. Some IPS station commanders still question the adequacy of initial training, but they are continuing training at the station level. 
IPS personnel with previous police or military experience attend the three-week Transition Integration Program (TIP). To date, more than 35,800 veteran police have received the threeweek TIP training. Almost all eligible veteran police still on the force have now completed the program. In the past quarter, more than 17,000 police personnel have received additional specialized training on subjects as diverse as interrogation procedures, counter-terrorism investigations, and election security. Annual refresher training for serving police has also been implemented, with more than 6,600 serving police officers already completing the three-day course.

\section{Recruitment and Vetting}

The work of the Ministry of Interior Qualifying Committee (MOIQC) to weed out "ghost employees" (who are being paid but not working) and other police who do not meet minimum standards continues. The MOIQC continued its biometric data collection efforts that will assist in proper vetting of the MOI employees and support the separation of unqualified Iraqi Police Officers. To date, the MOIQC has collected approximately 150,000 personnel profiles and is expected to complete collection in 15 of the 18 provinces during the forth quarter. Profiles collected by the MOIQC will eventually be linked to human resources and pay; the Ministry of Interior has not yet initiated the process of dismissing those employees who are being paid but not working.

\section{Equipment}

The IPS uses a variety of equipment: small pick-up trucks, mid-size sport utility vehicles, medium pick-ups, AK-47s, PKC light machine guns, Glock pistols, high frequency radios, and body armor. Logistics capabilities continue to be an area of concern for the IPS, particularly regarding vehicle maintenance and distribution of supplies and equipment. Construction of IPS stations has slowed due to insurgent intimidation and assassinations of construction personnel.

\section{$\underline{\text { Effectiveness }}$}

Absent without leave (AWOL) rates are a significant problem in areas where there is considerable strife, such as Fallujah, Ramadi, and Samarra. This situation is largely attributed to intimidation by the insurgents. Absenteeism in the Iraqi Police Service is difficult to quantify because the patrol, station and traffic police are operating without significant transition team oversight. IPS absentee data will be more precisely known when International Police Liaison Officers are more readily able to work at local police stations on a regular basis.

To further the development of the Iraqi institutional capability at the Ministry of Interior (MOI), the Civilian Police Assistance Training Team (CPATT) has established a multi-disciplinary coalition team to work with critical MOI personnel. Its task is to help build policy and procedures to enable the MOI to function more effectively as a national ministry. The team is based at MOI headquarters and comprises personnel from both CPATT and the Iraq 
Reconstruction Management Office. Development of administrative procedures for the dispersed IPS is a key task for this team.

Police Partnership Program (P3) teams are partnered at the provincial levels with the police to help identify areas of progress and shortcomings to determine when these forces will be able to assume independent control of their area of responsibility.

\section{Special Police Forces}

The Special Police Forces are a high-end, elite paramilitary police force tasked with providing a national, rapid-response police capability to counter armed insurgency, large scale civil disobedience, and riots. There are 28 Special Police Force battalions capable of combat operations - an increase of 13 since the last report. The Special Police include three separate organizations: the Special Police Commandos (providing light infantry for counter-insurgency operations), the Mechanized Police (providing light armor for counter-insurgency operations), and the Public Order Police (specializing in re-establishing order in high-risk environments). Along with the Iraqi Army, the Special Police Commandos and the Public Order Police contributed prominently in operations in Tal Afar. The assignment of the $1^{\text {st }}$ Special Police Mechanized Brigade to provide route security was key in reducing the incident of insurgent attacks along the highway from the International Zone to Baghdad International Airport.

\section{$\underline{\text { Special Police Commandos }}$}

Almost 10,000 Commandos have been trained and equipped, an increase of almost 2,000 since the last report. MNSTC-I is therefore currently ahead of its projection to train and equip 9,800 Commandos by the October 15 referendum. The Government of Iraq has authorized a total force of more than 11,800 Commandos, which MNSTC-I plans to train and equip by May 2006. New recruits to the Special Police Commandos, who typically are seasoned military veterans, undergo six weeks of intense training at the Special Police Commando academy in northern Baghdad. Each training cycle is designed to accommodate 300 to 500 students. The syllabus spans weapons qualification, urban patrolling techniques, unarmed combat apprehension, use of force, human rights and ethics in policing, introduction to Iraqi law, vehicle check points, and improvised explosive device characteristics and recognition. The effectiveness of the Special Police Commandos has been established in numerous operations. They have repeatedly demonstrated willingness to engage the enemy in locations such as Samara and Baghdad (including Haifa Street).

As stated in the last report, the Special Police Commandos' equipment is non-U.S. in origin with the exception of the primary tactical vehicles. Small arms and crew-served weapons are principally Glock pistols, Eastern-bloc AK-47s, rocket-propelled grenades (RPGs), and RPK and PKM light machine guns. Most organizational clothing and individual equipment is manufactured in Iraq. 


\section{Mechanized Police}

Almost 1,200 Mechanized Police have been trained and equipped, an increase of 300 since the last report. MNSTC-I has now reached the target force structure authorized by the Government of Iraq, so further basic training is necessary only for force sustainment. In conjunction with their operational mission, the brigade is undergoing Armored Security Vehicles (ASV) transitional training at Camp Taji, just north of Baghdad. The two-week transition course focuses on vehicle operations, communications, and vehicle maintenance.

One battalion of Mechanized Police is equipped with Russian BTR-60s armored wheeled vehicles fitted with 23mm cannons. Although some of these vehicles were recovered from the former regime, others were donated by Jordan. Two battalions of ASVs will eventually round out the brigade. These ASVs are armed with .50 caliber machine guns.

\section{$\underline{\text { Public Order Police }}$}

The Public Order Police complete the Special Police triad. Almost 7,000 Public Order Police have been trained and equipped, an increase of 1,200 since the last report. MNSTC-I is therefore currently on track to train and equip its target of 7,400 Public Order Police by the October 15 referendum. The Government of Iraq has authorized a total force of approximately 10,600 Public Order Police, whom MNSTC-I plans to train and equip by May 2006. Public Order Police receive six weeks of training at Camp Numaniyah, with a syllabus similar to that of the Special Police Commandos.

The Public Order Police use a variety of equipment: Chevy Luv pick-up trucks, mid-size sport utility vehicles, Nissan pick-up trucks, AK-47 assault rifles, PKC light machine guns, Glock pistols, high frequency radios, and body armor. As noted in the last report, each battalion and member is currently equipped with all mission-essential equipment.

\section{Effectiveness}

Leadership in the Special Police Forces is evaluated monthly using the Transition Readiness Assessment (TRA) system. Special Police Transition Teams are collocated with special police in the field, where they provide daily mentoring on proper police procedures as well as preventing human rights violations. The Civilian Police Assistance Training Team support personnel and International Police Liaison Officers make unannounced visits to special police force sites to assess progress, particularly regarding detainee handling. Allegations of detainee abuse and extra-judicial police actions by the Special Police Commandos are cause for concern. The MNF-I, MNSTC-I and the U.S. Embassy-Iraq are taking immediate steps to ensure Iraqi investigation of abuse allegations and to promote public reporting on the investigations, aiming thereby to build public confidence in Iraqi Special Police Forces.

Although the allegations of misconduct are troubling, the Special Police Forces provide a significant capability to the Ministry of Interior, and the growing pride and dedication of its 
personnel are demonstrated by their operational successes and a minimal rate of absent without leave (AWOL). Strong leadership, key to the continued development and professionalism of these three organizations, is routinely demonstrated by the junior officers and young noncommissioned officers.

\section{Emergency Response Unit}

The Emergency Response Unit (ERU) is a small, elite, national unit trained for high-risk search, arrest, hostage rescue, crisis response, and explosive ordnance disposal missions. During the past quarter, the ERU operated nearly nightly in both Mosul and Baghdad. After depleting the target insurgent population in Mosul, the contingent there re-deployed to Baghdad for continuing operations in support of security for the upcoming constitutional referendum and national elections.

Approximately 300 ERU members have been trained and equipped, an increase of 100 since the last report. MNSTC-I is therefore currently on track to train and equip its projection of 300 ERU members by the October 15 referendum. The Government of Iraq has authorized a total force of almost 750 ERU members, whom MNSTC-I plans to train and equip by November of this year.

The ERU training consists of a four-week basic training course and a four-week advanced course. Courses include instruction on basic handling of detainees, human rights training, target reconnaissance, physical fitness, and basic mission planning. For selected personnel, this training is followed by an eight-week Explosive Ordnance Disposal course or a six-week Intelligence/Surveillance course. While an average of $15 \%$ of personnel are dropped from each basic course, the ERU currently experiences minimal rates of absent without leave (AWOL).

The ERU receives strong mentorship, through contract support, from former U.S. special operations personnel, who develop leadership and mission planning and execution capabilities. The ERU consistently demonstrates strong officer and non-commissioned officer leadership. Senior leadership is still learning how to use a competent non-commissioned officer level of leadership.

\section{Border Forces}

Approximately 17,000 Border Police have been trained and equipped, an increase of 1,500 since the last report, but lagging the projection of 21,000 border forces by the October 15 referendum. The Government of Iraq has authorized a total force of more than 28,300 Border Police, which MNSTC-I plans to train and equip by May 2006. These forces are organized into 36 battalions that will man the 258 border forts around Iraq. As of September 20, 152 forts have been completed, with a total of 250 projected to be reconstructed or renovated by November 30, 2005; all border fort construction is scheduled to be complete by January 2006. To stem the flow of foreign fighters from Syria, priority of work in recent months has been on the Iraqi-Syrian border. The Ninewah and al-Anbar Brigades are each working their way to the Euphrates River, restoring border control as they progress. Border units in the region are supported by ten-person 
Border Transition Teams (BTTs). The BTTs' members are trained in various specialties, including logistics and communications, and provide critical assistance to the border force commanders in the areas of personnel management, intelligence, operations, budgeting, and equipment accountability/maintenance.

Equipping requirements for border forts and unit headquarters were determined earlier this year. Delivery has been tied to development of an accountability system. Typical organizational equipment includes small and medium pick-up trucks, mid-size sport utility vehicles, generators, and base radio stations. Personal equipment (e.g., AK-47 rifles, individual body armor, and medium machine guns) completes the outfitting of the border forces.

Three academies with a capacity of 800 each are utilized for training border patrol students. Border training focuses on an introduction to law enforcement, human relations, human rights, weapons qualification, combat life-saving, vehicle searches, Iraqi border law, arrest and detainee procedures, and small unit patrolling. The curriculum undergoes regular modification in response to the evolving threat environment.

The decentralized and dispersed nature of this force has fostered an environment in which corruption, "ghost" employees, and absent without leave (AWOL) rates remain a significant concern. As mentioned in the last report, some areas of the border appear to have a high level of insurgent infiltration. Coalition advisors are assisting Iraqi Department of Border Enforcement (DBE) leadership in rectifying these problems. A Transition Readiness Assessment (TRA) is being developed for the border forces. Until the TRA is fielded, evaluation of the border forces is conducted informally. The border force TRA reports will commence in October 2005.

\section{Iraqi Highway Patrol}

The Iraqi Highway Patrol (IHP) is a national force tasked with securing the main highways. The IHP includes performing armed escort and law enforcement duties along Iraq's highway system. Command and control of the IHP remains a contentious issue. The force was designed to be a national one, but has been subordinated to the provincial police departments. This turmoil has disrupted the IHP, causing a slight decrease since the last report to approximately 1,300 patrolmen, and below the projection to train and equip 1,600 IHP by the October 15 referendum. The Government of Iraq has authorized a total force of 6,300 patrolmen, which MNSTC-I plans to train and equip by August 2007. Discussions with ministry leadership are ongoing to address the command and control issues.

As discussed in the last report, IHP officers must first qualify as police officers before attending a follow-on four week training program at Taji Highway Patrol Academy. The follow-on training covers basic policing, driving skills, convoy escort, and weapons qualification with pistol, rifle, and machine gun. The course was extended from three to four weeks in July 2005 to provide a more robust syllabus. 


\section{Equipment}

The IHP is equipped with small pick-ups, mid-size sport utility vehicles, medium pick-ups, AK47 rifles, PKC machine guns, Glock pistols, high frequency radios, and body armor. Distribution of supplies and equipment, as well as additional logistical and pay issues, continue to challenge the effectiveness of the IHP.

\section{Effectiveness}

A Transition Readiness Assessment will be conducted on the IHP National Headquarters and eight operating IHP stations by November 2005. Informal assessments currently being provided indicate that leadership in the IHP remains an issue. Some of the senior officers are extremely competent, while others still need considerable improvement to be effective independent of Coalition support. The absent without leave (AWOL) rates have not yet been assessed.

\section{Center of Dignitary Protection}

Approximately 600 personnel have been trained and equipped for the Center of Dignitary Protection (CDP). Training for personnel consists of four sub-courses: Tier I Personal Security Detachment (PSD) (five weeks), Tier I Motorcade Escort (four weeks), Tier I Site Security (two weeks), and Tier II PSD (four weeks). Courses emphasize defensive and lifesaving driving skills, site security, control point access, bomb threat actions, improvised explosive device counter-measures, facility and route reconnaissance, security functions, and basic life saving.

Although no official Transition Readiness Assessment exists for the CDP, contract mentors and advisors attached to each team provide detailed assessments. The procedures utilized by the CDP Tier I PSDs are continually evaluated and modified to increase effectiveness. Each PSD is provided basic equipment kits. During the month of September, thirty armored vehicles were issued to the Tier II PSDs. 


\section{Criteria for Withdrawing Forces}

U.S. forces will withdraw from Iraq as their mission is successfully accomplished. As noted in the July report, criteria for withdrawing Coalition Forces from Iraq are conditions-based, not calendar-based. There is not a timeline or milestones that directly tie the drawdown of Coalition forces to increased numbers of capable Iraqi battalions. Drawdown will occur in a phased, gradual manner as Iraqi forces become capable of taking the lead within areas of Iraq and in concert with Iraqi progress in political and economic capabilities.

To assist in determining when conditions permit handing over security responsibility from Coalition Forces to Iraqi Security Forces (ISF), the United States, the Iraqi government, and our Coalition partners have established the Coalition-Iraqi Joint Commission to Transfer Security Responsibility from Coalition Forces to ISF. Transfers will be effected on an area-by-area basis and will occur only with the approval of the Iraqi Prime Minister, the U.S. Ambassador, and the Commanding General, Multi-National Force-Iraq. Transfer of responsibility will depend on achieving conditions for each area in such categories as:

- levels of present and projected insurgent activity;

- readiness and capabilities of Iraqi Security Forces;

- readiness and capabilities of relevant government institutions; and

- ability of Coalition Forces to reinforce the ISF should this become necessary.

The ability to meet these criteria will continue to be affected by progress in political, economic, and other areas.

As reported previously, other conditions that will support and hasten success include the continued reconciliation of the various ethnic communities in Iraq. Recent polling data indicate that the various groups within the Iraqi body politic have made impressive progress towards coexistence within a political process. Additionally, the increase in registered voters, combined with polling data that indicate that Sunni Arabs believe that it was a mistake to boycott the January election, indicate that the Iraqi people are becoming active stakeholders in their own future. This will have an important impact on the security situation.

The expanded engagement of the international community is vital for the security situation within Iraq and in the region. Continuing United Nations and NATO commitments are similarly critical to Iraqi and regional stability and security. The March 2005 Arab League summit ended with a promise for increased diplomatic representation between its member states and Baghdad, along with a call to restructure Iraq's debt within the Arab League. The engagement of Iraq's neighbors will be critical to encouraging the Iraqi people to move peacefully down the path of political progress, as well as closing down the continuing stream of foreign terrorists entering Iraq. 